\title{
A Review of Evidence about Equitable School Leadership
}

\author{
Kenneth Leithwood
}

check for

updates

Citation: Leithwood, K. A Review of Evidence about Equitable School Leadership. Educ. Sci. 2021, 11, 377. https://doi.org/10.3390/

educsci11080377

Academic Editor: Judith Könemann

Received: 11 June 2021

Accepted: 14 July 2021

Published: 23 July 2021

Publisher's Note: MDPI stays neutral with regard to jurisdictional claims in published maps and institutional affiliations.

Copyright: (C) 2021 by the author. Licensee MDPI, Basel, Switzerland. This article is an open access article distributed under the terms and conditions of the Creative Commons Attribution (CC BY) license (https:// creativecommons.org/licenses/by/ $4.0 /)$.
Department of Leadership, Higher and Adult Education, University of Toronto, Toronto, ON M5S 1A1, Canada; kenneth.leithwood@utoronto.ca

\begin{abstract}
This paper reviews the results of 63 empirical studies and reviews of research in order to identify those school leadership practices and dispositions likely to help improve equitable school conditions and outcomes for diverse and traditionally underserved students. Guided by a welldeveloped framework of successful school leadership, results indicate that most of the practices and dispositions in the framework can be enacted in ways that contribute to more equitable conditions and outcomes for students. A handful of these practices and dispositions appear to make an especially significant contribution to the development of more equitable schools as well as several additional practices and dispositions associated with equitable leadership merit mastery by equitably-oriented leaders. Among the especially significant practices are building productive partnerships among parents, schools, and the larger community as well as encouraging teachers to engage in forms of instruction with all students that are both ambitious and culturally responsive. Leaders are likely to be more effective when they adopt a critical perspective on the policies, practices, and procedures in their schools and develop a deep understanding of the cultures, norms, values, and expectations of the students' families. The paper concludes with implications for practice and future research.
\end{abstract}

Keywords: school leadership; social justice; inclusive schools; equitable leadership; leader dispositions; leadership practices; leadership effects

\section{Introduction}

The inequitable treatment of diverse groups of children in schools has been a concern for policy makers and practicing educators in many countries for decades. This concern was, for example, the foundation of the "effective schools movement" in the 1970s [1], a movement aimed at improving equity, especially for low socio-economic status (SES) black children in inner city schools; it also gave rise to school desegregation in parts of the U.S. [2] and transformed approaches to educating students with special needs in many countries by mandating "least restrictive environments" [3]. The introduction of state-wide testing programs requiring the disaggregation of results by at least student SES, along with sanctions for schools failing to make annual progress in closing achievement gaps [4], was also a response to inequity concerns.

Contemporary expressions of concern about inequity have been prompted by evidence about race-based differences in how schools implement their discipline policies [5,6] and the seemingly intransigent challenges schools face when confronted with significant increases in immigration [7]. A spotlight has been shone, most recently, on how deeply into our social fabric are the roots of social injustice [8-10] by striking variations in the risks encountered by, and the resources available to, families and their children during the Covid pandemic. Concerns about inequity have never been more widespread or garnered more public energy than they do now.

The longstanding nature of concerns about inequity demonstrate how complex the problem has been to address. Evidence accumulated over the past several decades, however, has provided key insights into promising elements of the solution. One of these insights is just how pivotal school leaders are to the success of almost any significant change in schools [11,12]. Regardless of the solution of choice for improving equity, school leaders 
and their staff have almost always been at the pointy end of delivering that solution. In acknowledgement, many leadership scholars have turned the focus of their research toward discovering what school leaders do, who are successful at improving equity in their schools.

The purpose for this review of research is to summarize the results of recent empirical research generated by those scholars. More specifically, the paper:

1. reviews evidence about how the core leadership practices and dispositions included in a well-developed educational leadership framework (described below) are enacted when improving equity in a school is the objective;

2. identifies leadership practices and dispositions contributing to more equitable schooling not yet included in that leadership framework but potentially valuable additions to the framework should it be revised.

For the purposes of this review, leadership is conceptualized as the exercise of influence on organizational members and diverse stakeholders toward the identification and achievement of the organization's vision and goals. This influence may have many sources (e.g., administrators, parents, teachers, trustees), is typically reciprocal rather than unidirectional, and is exercised through relationships between and among individuals, groups, and the settings in which they find themselves. Leadership, defined in this way, is "successful" to the extent that it makes significant, positive, and ethically defensible contributions to progress in achieving the organization's vision and goals.

The term equity, as used in this paper, is distinct from the term equality. While the term equality suggests that all students should have access to the same educational resources and opportunities, the term equitable acknowledges that some students need more of the school's resources and opportunities than others in order to achieve the same levels of success. The paper also uses equitable as a superordinate term encompassing related concepts such as social justice and inclusion. The sources of inequity serving as the focus of leaders' attention in the studies included in the review encompass, for example, various forms of disability, language, culture, sexual orientation, ethnicity, race, social class, color, and poverty. Individual students frequently experience multiple sources of inequity at the same time.

\section{Framework}

The framework guiding the review was based on an integrated conception of successful school leadership along with an accumulation and ongoing synthesis of evidence carried out over several decades. Samples of this evidence can be found in [11-20].

Including five domains of leadership practices and three categories of dispositions, the guiding framework was built on an underlying theory of human performance as a function of motivation (influenced through the Setting Directions domain), ability, or knowledge/skills (the focus of the Developing People domain) and the setting or context for performance (the Organizational Design domain). Successful leadership depends on positively influencing these three features of human performance among members of the organization.

This theory has been expanded with two additional domains of practice (subsumed by the Organizational Design domain) that are unique to educational settings. One of these domains, Improving the Instructional Program, reflects the well-documented claim that a considerable proportion of the school leaders' attention should be devoted to the technical core of schooling: teaching and learning. The second additional domain, Securing Accountability, acknowledges the broad policy context that holds most school leaders accountable for advancing their schools' achievement of widely valued student outcomes. Four types of dispositions, referred to as Personal Leadership Resources, are also part of this theory. These dispositions include key personal qualities of leaders themselves that enhance the chances of them enacting desirable leadership practices and enacting them well. 
The framework has been subject to empirical testing by its developers as well as independent researchers, and this testing has resulted in further elaborations of the framework that have been published over the last eight years (e.g., [18,21,22]). A central motivation for conducting this review was to further refine and elaborate the framework.

\subsection{Leadership Practices}

Specific practices included in the five domains of the framework combine both instructional and transformational leadership practices reflecting an "integrated leadership model" (e.g., [23]) of leadership. Included also are practices not typically part of an integrated model. These are practices that previous reviews of evidence (e.g., [24-27]) have associated with "equity-oriented" or "culturally-responsive" leadership". These additional practices include, for example, building productive relationships with families, enhancing the school's connection with its wider community, collaborative decision making, the distribution of leadership among the school's stakeholders, staffing the instructional program, and the alignment of resource allocation with the school goals.

This review aims to determine what other practices (or adaptations of practices) equityoriented leaders need to enact in order to create more inclusive, socially just experiences for diverse groups of students in their schools.

The five domains of leadership practices include 22 specific practices:

- Setting Directions includes Building a shared vision; Identifying specific, shared, shortterm goals; Creating high-performance expectations; and Communicating the vision and goals;

- Building Relationships and Developing People includes Stimulating growth in the professional capacities of staff; Providing support and demonstrating consideration for individual staff members as well as Modelling the school's values and practices. Included also in this domain are Building trusting relationships with and among staff, students and parents, and Establishing productive working relationships with teacher federation representatives;

- Designing the Organization to Support Desired Practices includes Building collaborative cultures and distributing leadership; Structuring the organization to facilitate collaboration; and Building productive relationships with families and communities. This domain also includes Connecting the school to its wider environment; Maintaining a safe and healthy school environment; and Allocating resources in support of the school's vision and goals;

- Improving the Instructional Program includes Staffing the instructional program; Providing instructional support; and Monitoring student learning and school improvement progress. Included also in this domain are Buffering staff from distractions to their work and Participating with teachers in their professional learning activities;

- Securing Accountability includes Building staff members sense of internal accountability and Meeting the demands for external accountability.

The review aimed to answer three questions about leadership practices:

1. Which of the practices in the framework, suitably enacted, contribute to improving equity in schools?

2. Do some of the practices in the framework make especially important contributions to improving equity in schools?

3. Are there additional leadership practices important for improving equity not included in the framework?

\subsection{Leaders' Dispositions (or Personal Leadership Resources-PLRs)}

Significant evidence now supports the positive impact of dispositions on the contribution leaders make to those served by their organizations [28,29]. The guiding framework includes four categories of dispositions, attributes, or personal leadership resources: cognitive, social, and psychological resources as well as values and ethics. Cognitive resources include problem-solving expertise; systems thinking; and several types of role-related and 
organizational improvement knowledge. Social resources, largely encompassed in most accounts of "social appraisal skills" or "emotional intelligence", include the leaders' abilities to perceive the emotions of others, manage their own emotions, and act in emotionally appropriate ways. Psychological resources include optimism and resilience, self-efficacy, and proactivity.

Many decisions faced by leaders are ethical dilemmas and almost all decisions are influenced, one-way or another, by the leaders' values [30]. Considerable evidence associated with ethical leadership points to both personal and professional values influencing the leaders' success. Examples of personal values that evidence collected in Western contexts suggests are generally associated with ethical leadership (e.g., NPBEA ISSLC standards, 2015) include fairness, honesty, and integrity.

Among the most consequential professional value held by successful educational leaders is the primacy of the students' best interests in decision making. Among the other widely endorsed professional values are social justice and the equitable treatment of students regardless of, for example, their race, economic conditions, sexual orientation, cultural and ethnic background, or religious affiliation. Professional values such as these also reflect, in education contexts, accounts of ethical leadership across some non-education contexts.

The review aimed to identify any additional dispositions especially useful for leaders aiming to improve equity in their schools.

\subsection{The Complication of Context}

While much of the research included in this review reflected elements of the framework, one goal of the review was to discover what was missing when improving the equitable treatment of students is the goal. This meant explicitly not "forcing" the results of the research into "boxes" predetermined by the framework; this was more complicated than it might seem, however, because of the part that contexts play in shaping the nature of the leaders' work.

An overwhelming amount of evidence as well as professional opinion indicates that a leaders' success depends not only on using effective practices, but also using them in ways that are appropriate to the leader's context [11]. While this seems an obvious enough assertion, the wide variety of "contexts" leaders face substantially complicates matters. The "context" can be many things such as the goals to be accomplished in the school, resources available to the school, school size, the types of students served by the school, the nature and aspirations of students' families, the levels of expertise of the school's staff, and district and government policies that the schools and their leaders are expected to acknowledge in their work. Effective leadership is "adaptive and responsive to the changing conditions of the school over time" [31] (p. 121). Similarly, as one extensive three-year study concluded, leaders are successful "through who they are-their values, virtues, dispositions, attributes and competencies as well as what they do in terms of the strategies they select and how they adapt their leadership practices to their unique context." [32] (p. 229).

Based on this understanding of how both internal and external contexts shape leaders' work, a central challenge for the analysis of studies included in the review was to distinguish between equitable leadership practices and dispositions that were conceptually different from elements of the framework and equitable leadership practices and dispositions that were contextually appropriate adaptations of some elements of the framework.

\section{Review Methods}

\subsection{Search Procedures}

This is a narrative review of research largely because the available evidence is not amenable to more quantitative review methods. Nonetheless, the review aims to be as systematic and transparent as possible about sources of evidence, how those sources were selected, and how knowledge claims from the review were justified. 
The search for studies to be included in the review reflected the basic features of a snowball sampling technique, one that was more focused and targeted than would have been the case had the search relied primarily on commonly used search engines (e.g., Web of Science, ERIC). While no claim can be made that the final set of studies included in the review is an exhaustive set, the snowball sampling technique is likely to have produced a corpus of studies whose results represent, reasonably well, the collective results of most studies about equitable school leadership. Nonetheless, not using the commonly used search engines could be viewed as a limitation of this study.

Google Scholar and the keywords Leadership and Equity, Social Justice, Inclusive, Student Outcomes, and School Conditions were used to launch the search. Restricted to the period 2010 to 2020, studies initially considered eligible for review:

- $\quad$ had to be published in English;

- report original empirical evidence;

- include some measure of leadership;

- include some measure of student outcomes;

- be reported in a peer reviewed journal.

No restrictions were placed on the methods used in the studies selected, so they could be qualitative or quantitative in nature, for example, and vary widely in sample sizes.

The five selection criteria eliminated a very large proportion of the literature about equitable school leadership, in particular, studies describing what self-identified equityoriented school leaders do in schools serving highly diverse student populations, but without providing empirical evidence distinguishing more from less successful leadership practices or dispositions.

Descriptive studies of this type constitute a large proportion of the literature about equitable school leadership [33] although they do not contribute to the empirical justification for effective equitable leadership practices and dispositions that this review initially aimed to provide. Studies of this type, however, often serve valuable purposes: they draw attention to neglected problems, paint a picture of typical practice, illustrate approaches to leadership consistent with theories of inclusion, social justice, and several types of critical theory, and offer potentially valuable directions for further exploration.

Results of many such descriptive studies also have high levels of "face validity". For example, it seems reasonable to expect that staff members unaware of their own racial biases, need to be challenged in some fashion by their school leaders if those biases are to be disrupted. It seems clear that students traditionally struggling at school need more engaging and meaningful curricula that acknowledge their own lived experiences in some fashion. To provide the kind of guidance to schools serving families and communities sidelined from decisions about their children's education, it seems obvious that a thorough understanding of the cultures and norms of those families and communities need to be deeply understood by those providing leadership as well as by their teaching colleagues. For these reasons, the original search was expanded to include a significant sample of studies meeting all but one of the original search criteria (evidence of student outcomes) for inclusion in the review.

Part of the initial search process also included publications by researchers belonging to two large international research collaborations about which the reviewer had prior knowledge, the International Successful School Principalship Project (ISSPP) and the International School Leadership Development Network (ISLDN). Members of both of these collaborations have inquired about leadership practices and dispositions successful in creating greater equity in schools serving students and communities facing significant challenges ("high needs" schools, schools focused on social justice). Journal articles published by these researchers were included in the review when they met the five original eligibility criteria described above.

An ancestry approach was also part of the search procedures. References cited by initially selected studies were examined to further identify relevant literature missed in the initial search. The reference lists of studies identified through the initial search process were 
reviewed and analyzed for additional eligible studies. The reference lists of this second round of eligible follow-up studies were also examined and their reference lists searched.

Preliminary analysis of all of the studies identified using these search procedures failed to reveal a single large-scale empirical study testing the contribution (either direct or indirect) of some explicit model or conception of effective equitable leadership to some desirable set of student outcomes. As a result, personal contacts were made with 12 mostly senior leadership scholars intimately familiar with quantitative educational leadership research, several of whom were also long-time editors of relevant peer-reviewed journals. These contacts were asked if they could identify any relevant large-scale quantitative studies; none were identified.

In an additional effort to ensure that no large-scale empirical studies were overlooked, a manual search was then undertaken of all issues, between 2010 and 2020, of six highly ranked journals that regularly report quantitative studies about educational leadership, management, or administration (Educational Administration Quarterly, Journal of Educational Administration, Leadership and Policy in Schools, School Effectiveness and School Improvement, School Leadership and Management, International Journal of Leadership in Education, Educational Management, and Administration and Leadership. These are largely the same journals used to represent the field of educational administration by Oplatka [34] in his historical analysis of the field). This search turned up nine large-scale quantitative studies, in addition to several previously unidentified qualitative studies. While none of the nine studies explicitly claimed to be focused on equitable leadership, all of them tested the effects of selected leadership practices in schools serving high proportions of traditionally underserved students.

Finally, to account for significant results of research published prior to 2010, systematic reviews of research about equitable leadership practices and/or dispositions were examined. These reviews were also published in peer reviewed journals between 2010 and 2020.

\subsection{Nature of the Evidence}

The final number of studies included in the review was 64 and the results of these studies are reported in two main sections. The first section of the results includes a subsection describing the results of 26 qualitative and mixed-methods studies and a subsection reporting the results of 10 large-scale empirical studies; both sets of studies include evidence of the effects on students of those leadership practices and PLRs that they identify. This division into two subsections reflects the substantial differences that exist in the initial assumptions, conceptual orientations, and methodological strengths and limitations of each of the two types of studies.

The second section of the results includes a sub-section summarizing the results of seven reviews of theory and evidence included as a means of reflecting research published prior to 2010 and identifying prominent theories about equity with implications for leadership practices and dispositions. A second sub section summarizes the results from a sample of 21 descriptive studies of the practices and dispositions of self-identified social justice school leaders with no evidence (positive or negative) of impact on students reported.

\subsection{Analysis of Evidence}

Deductive coding was used to analyze the results of studies reporting original data. The individual leadership practices, along with the dispositions included in the guiding framework, were the starting points for such coding. Only the author carried out this coding, a limitation of the review. However, the reporting of results includes extensive quoted material from individual studies, allowing readers to judge the extent to which they agree with the author's coding decisions. Additionally, a significant number of the studies included in the review actually used some or all the framework guiding this review as the framework guiding their research, making the deductive coding process much simpler in those cases. 


\subsection{Reporting Styles}

Different styles of reporting are used in each of the four sections of the results. The first section of results, by far the lengthiest, is aligned with each of the guiding framework's practices in order to (a) demonstrate the contribution that almost all of the leadership practices in the framework make to achieving equity in schools; and (b) illustrate how each of the practices in the framework has been productively adapted by samples of school leaders when their goal was to achieve greater equity, inclusion, and social justice for their students. This section does not touch on the leaders' dispositions for two reasons; they are not mentioned much in the results of this group of studies and most dispositions that are mentioned are among those already included in the framework.

The second section of results, also focused only on leadership practices, includes a review of 10 large-scale empirical studies separately. This is necessary because of differences in their conceptual orientations, analytic methods, and the need to explain the relevance of these studies to the main focus of concern in the review.

The seven reviews of literature included in the third section of the results are explicitly guided by theories of social justice, inclusion, and critical theory with implications for the work of school leaders. These reviews are reported separately in order to capture the nature of each of the theories themselves as well as differences in their implications for leaders. The fourth section of results provides a brief "profile" of equitable leadership built on evidence from 19 studies of leaders identified as especially focused on social justice in their schools. This profile highlights many of the possible additions that could be made to the framework for leaders with a vision of equity and a commitment to improving equity for students in their schools.

The results reported in Sections 3 and 4 identify a significant number of leader dispositions, which are summarized in Section 3.5.

\subsection{Section One Results}

\subsubsection{Qualitative and Mixed Methods Studies with Evidence of Outcomes}

Of the 26 studies included in this section of results (see Appendix A), one was an experiment [35] while the remainder used "outlier" designs, that is, case studies of schools and leaders selected because of their unusually successful performance. In most studies, student achievement was the measure of school and student success. While one of these studies included 14 elementary and secondary schools [36], most used much smaller samples: 11 studies were conducted in a single school, 13 in two to four schools, and two studies in five or six schools.

The 26 studies, as a whole, were conducted in urban, suburban, and rural schools located in a wide variety of national contexts and cultures including Cyprus (e.g., [37]), New Zealand (e.g., [38]), Canada (e.g., [39]), Lebanon (e.g., [40]), Hong Kong (e.g., [41]), the U.S. (e.g., [42]), England [36], and Australia [43]. Students included in the study schools were often minoritized and economically challenge, as well as speaking a language at home other than the language of instruction. Religion, ethnicity, and (dis)ability or "special needs" were other forms of student diversity in the study schools.

The remainder of this sub-section describes the results of these studies in relation to each of the detailed practices in the guiding framework. In most cases, this description begins with a synthesis of results across all relevant studies, followed by reports of how the practice was enacted in one or two illustrative studies. From a third to a half or more of the 26 studies reported evidence about practices in four of the five domains (not Securing Accountability).

\subsubsection{Domain 1: Set Directions}

Evidence about leadership practices in this domain indicates considerable overlap among the four, specific, direction-setting practices, most reinforcing the purposes served by the others. 
Build a shared vision. Approaches to vision building by equitable school leaders are widely shared with either the direct or indirect participation of students' families and the communities of which they are a part. Equitable school leaders both espouse and demonstrate, through their actions, strong personal commitments to the success of all of their students. Their vision-building practices are adapted to the communities served by their schools.

Examples. A highly community-driven approach to setting directions is described in Green's study [44] of urban reform and community development in two schools predominantly populated with students of color from low-income backgrounds. One of the two principals in this study acted more as a facilitator and connector supporting the work of community-based leaders in their efforts to define and provide the type of schooling they wanted for their children. This required the principal to spend significant time in the community to determine how the school could collaborate with other community organizations to help achieve a community-wide vision that included the school.

A more principal-driven approach evident in Klar and Brewer's [45] case study of a principal's leadership in one high poverty, rural, middle school illustrates, in more detail, one approach to setting directions aimed at improving equity for students related to academic achievement. Clearly principal initiated, this approach is associated with typical school turnaround processes, less shared at the outset, but with productive longterm results in some contexts. During the seven-year tenure of the principal, the school moved from the lowest to the highest performing school in its district and was the highest achieving of all demographically similar schools in its region.

In the principal's own words, the improvement process began at a district principals' meeting in which he participated shortly after his appointment to the school:

"So, I came back to my faculty, and I got them in there, and I said, Let me tell you something. I sat through an embarrassing meeting. I said, I'm not sitting through that next year. I said, We've got this test coming up at the end of this year, and we're going to do something. We're not going to be last on everything". [45] (p. 432)

To set a positive direction in the school, the principal enacted most of the specific practices included in the guiding framework's direction-setting domain. The principal's vision grew out of a combination of his own desire for more equitable student outcomes and the community's desire to have a school they could be proud of. He built a shared vision by encouraging a family atmosphere in the school and by "recognizing both students and teachers for various achievements" in a variety of ways including awards. The school's new direction was communicated to staff and parents, and the principal visibly and vocally held high expectations for both teachers and students. Teachers noted that they were aware of the principal's high expectations for them, but also that the principal was highly supportive of their efforts to meet those expectations. Said one teacher:

[our principal] has fought hard to make both students and parents realize that true success in life can be achieved through education. That students can be more than the poor circumstances that may surround them. [Our principal] has challenged all of his staff to not accept the culture of apathy. We continually push our students to do better, not to accept "alright". This is a constant struggle for us as teachers and for our students to grasp and understand. But it is a fight we are unwilling to give up on. [45] (p. 434)

Identify specific, shared, short-term goals. Identifying short-term goals is a means used by leaders to connect broad visions for their schools to the day-to-day activities required of staff, parents, and students if the broad vision is to be realized. These day-today activities have to be supported and nurtured by school leaders when others are in the best position to carry them out. However, school leaders are sometimes able to enact such activities themselves directly with students. 
Studies in this section of the review had little to say explicitly about this leadership practice with staff or parents, independently from other practices. It was largely through some of those other practices that specific goal clarification occurred, for example, Modeling the school's goals and values, Building productive relationships with parents and the community, and through the feedback provided to teachers while Monitoring student learning. In addition, some studies have portrayed specific goal setting as an iterative, ongoing process extending over time and in response to the leaders' gradually improving understandings of what would be required to achieve the vision established for their schools (e.g., [36,46,47]): this iterative process is especially evident in studies of leaders engaged in "community organizing" approaches to improving equity in their schools, which is discussed more fully in a later section.

Examples. One vivid illustration of iterative goal setting can be found in an Australian study about the development of a "second chance" secondary school, a school that continued to serve about 100 senior secondary students after a 12-year period [48]. Describing how the two founding teachers (the study authors) used critical action research methods, the focus of the study was on the initial three and a half years of the school's development. During that period, the two teachers pursued the same vision for the school, engaging disenfranchised young people back into formalized senior secondary schooling. However, over three cycles of inquiry, the two teachers became much more knowledgeable about the short-term goals they would need to address if this vision was to materialize. For example, they describe some of their early efforts as follows:

We met with regional youth stakeholders we believed could offer us forms of support for a second chance schooling initiative. In these meetings we foregrounded the development of a new schooling model for those students who had left secondary schooling without a career plan in mind or a job in sight. These discussions gathered momentum over time. As we recognized gathering community support, we became more strategic in our work, endeavoring to capitalize upon community interest and momentum. We then worked to bring all of the youth stakeholders together in a Regional Youth Forum that we hoped would have enough 'political punch' to move awareness of and concern about the issues of youth disengagement from schooling into the broader community. [48] (p. 506)

At a later stage of their work, the two teachers aimed to acquire a suitable physical space for the school on a nearby college campus. As they explain:

This 'quality' educational space was very important to us because the alternative programs we had seen and been involved in over our extensive educational careers were typically located in the 'backblocks of the school', often in dilapidated buildings. Many teachers called these places 'Siberia'. We believed this schooling approach said a lot to young people about how much the school really cared about their welfare. Students merely had to look at the building to know where they were positioned in terms of the school's priorities. [48] (p. 507)

Additional short-term goals continued to surface over time such as finding and hiring suitable staff, enrolling students who could benefit from the school, communicating the establishment of the school to the wider public, creating a curriculum and developing forms of instruction best suited to the needs of the students, and engaging in the political action required to obtain permanent funding for the school from the state government.

A second study, the only experiment in this category of studies [35], illustrated the positive consequences of establishing and communicating explicit short-term goals, in this case, through the direct interaction by the principal with students struggling to improve their reading achievement. The experiment occurred in one large suburban U.S. middle school and included the majority of grade 8 students considered non-proficient in reading. Twenty students were randomly assigned to a treatment group and 21 to a control group. The authors describe the treatment as follows: 
In the experimental condition, students met twice individually with a principal during the month immediately prior to the eighth grade 2009 PSSA Reading Test. During the first meeting, the principal and the student engaged in a 15-min achievement-based discussion. The discussion protocol focused on six components: (a) introductions and general discussion to put the student at ease; (b) a statement of the school mission and the principal's high expectations for students' improved reading performance; (c) a review of the student's individual achievement report from the seventh grade 2008 PSSA Reading Test including identification of the student's overall level of performance, areas of relative strength, and areas of relative need; (d) identification of the Pennsylvania Value Added Assessment System (PVAAS) projected score for the student; (e) collaboratively setting a goal for the student's percentile score on the eighth grade 2009 PSSA Reading Test; and (f) expressions of appreciation, support, and encouragement to the student by the principal. In the second meeting, the principal conducted a follow-up discussion within a week prior to the mid-March administration of the 2009 PSSA Reading Test. [35] (p. 781)

Students in the control group also had achievement-oriented discussions with the principal but after, rather than before, the reading tests were conducted. Students in the experimental group scored significantly higher on the reading test than did students in the control group.

While this study illustrates an effective approach to specific goal clarification with students, it also provides an example of how a school leader managed to allocate a disproportionate amount of the school's resources (the principal's time and attention) to students most in need, as a means of achieving more equitable outcomes. The details of the interactions that occurred between the principals and students also indicate how a school leader can begin to develop a more caring climate for students in the school.

Create high-performance expectations. An extensive line of evidence demonstrates the power of others' expectations to influence one's efforts and subsequent performance [49]. Most studies in the review attributed the leaders' high expectations for students, staff, and parents to be an important part of how leaders improve equity in their schools. Gurr [50] reported that among the studies conducted by members of the International Successful School Principal Project (ISSPP), most conducted in "high needs" schools, the creation of high expectations surfaced as among the most important practices enacted by leaders who significantly improved student outcomes in high needs schools.

The knowledge, language, and culture students bring with them to school from their families and broader communities have often been viewed as deficits by some educators. Significant efforts have been made, however, to alter those views and to encourage educators to adopt an "assets-based" perspective on the diverse resources that students bring to school. Adoption of an assets-based perspective demonstrates the school's understanding and respect for the diverse needs and capacities of their students, encourages the school to use these understandings as pedagogical resources, and helps remove blinders on the school staff's expectations for the learning of typically underserved students. Encouraging staff to adopt an assets-based perspective on what their students bring to school from their families and communities is a powerful way for school leaders to communicate their high expectations for both students and teachers.

Example. Results of Okilwa and Barnett's study [47] illustrated how leaders help to create high expectations as well as the association between such expectations and assetbased perspectives on student potential. This study was about one Texas high needs school and the four sets of leaders who managed to sustain the high performance of the school's students over a 20-year period. During that period, the schools' student population gradually became more economically disadvantaged (91\% classified as such by 2013) and increasingly Hispanic ( $90 \%$ by 2013$)$.

High expectations were identified as one of four factors accounting for the school's success (the other factors were shared leadership, collective responsibility for student 
learning, and data-based decision making). High expectations were one of the "nonnegotiables" advocated by all four sets of leaders who were at the school over the 20-year period. Noted the authors, "To rally support toward a vision and mission of excellence, the leaders led by example: first by holding themselves to high standards [included in the guiding framework as Modeling the school's values and practices] and then requiring the same from teachers, students, and parents" [47] (p. 306). Creating high expectations began with the first of the school's four principals and vice-principals:

At the beginning of Ms. Williams' leadership era, [the school] was plagued by low teacher morale, low expectations for students, a deficit mentality toward student learning, and low performance on the statewide accountability system. This same deficit mindset was also true for most parents. Ms. Williams and her assistant principal, Ms. Peterson, had to overcome this deficit thinking by changing the culture and climate of Robbins through initiatives such as distributed leadership, curriculum and assessment alignment, collective responsibility for student learning, reflective dialogue, and increased teacher efficacy. Most importantly, Ms. Williams and Ms. Peterson modeled what it would take to turnaround [the school], particularly a strong work ethic, teamwork, and above average resolve. As teachers observed and started practicing these behaviors, the staff and parents began to see steady improvement in the students' academic performance. High expectations became part of [the school's] culture as teachers worked toward finding a way to ensure success for every child. [47] (p. 306)

The contribution of high expectations evident in this study is entirely consistent with the broader body of research about equitable leadership. For example, Khalifa, Gooden, and Davis's [26] review of research found that culturally responsive leaders hold and communicate high expectations for all students regardless of their racial and ethnic backgrounds and also strive to help students meet those expectations.

Communicate the vision and goals. The research indicates that equitable school leaders communicate their schools' visions and goals sometimes through formal processes highlighting those visions and goals and calling on staff and others to adopt them as their own. Equitable leaders also communicate their schools' visions and goals opportunistically, often through the priorities evident to others in how they use their own time. The need to communicate the school's directions seems to be self-evident if they are to serve any useful purpose. It is how this communication is done effectively that needs to be unpacked. Evidence indicates the importance of such communication being clearly associated with the school's strategies for accomplishing those directions.

Examples. One illustration of what this means is provided by a study of leadership in five rural schools in Cyprus [51] (p. 551).

People-centered leadership and clearly communicated values and visions combined with a strong emphasis on the promotion of learning, the use of networked leadership as well as the creative management of competing values outline the elements of a comprehensive and indeed, successful kind of leadership [51] (p. 501).

A second illustration can be found in a study carried out in three U.S. high poverty schools serving students achieving "beyond expectation" [52]. Evidence about the practices of one of these principals is reported as follows:

Many school administrators and staff recalled Principal Martin's radical appeal to communicate the direction by eliminating excuses. One department chair recalled a contract being drawn and signed by all, pledging that responsibility would be taken, rather than excuses made, for all facets of life. She reflected, "I think that we have done a really good job with the expectation here, because I don't think our students realize that they're not supposed to perform". [52] (p. 779) 
3.5.3. Domain 2: Build Relationships and Develop People (No Evidence Was Found for One Practice That Is Part of This Domain in the Guiding Framework (Establish Productive Working Relationships with Teacher Federation Representatives))

Stimulate growth in the professional capacities of staff. Staff development is an important practice for leaders successful at improving equity in their schools. Successfully improving equity in schools requires new skills, knowledge, and attitudes on the part of many staff and this puts a premium on ensuring opportunities for staff to develop these new capacities. Equitable school leaders understand the gaps that often exist between their staff's current practices and beliefs and the practices and beliefs needed to ensure more equitable opportunities and outcomes for underserved students in their schools.

Those few studies that actually described the qualities of effective professional development indicated that equitable leaders provide professional development, which is ongoing, includes opportunities for practice and feedback, and overtly challenges the beliefs and values antithetical to equitable practice. The individualized nature of some of this professional development is expanded in the evidence reviewed in relation to the next practice.

Examples. One study [42] illustrating an approach to this practice was about two U.S. schools and their principals successfully implementing an inclusive model of English Language Learning (ELL). These principals were:

... committed to the stance that all learners can succeed with appropriate and adequate support ... and ... they prepared themselves and their staffs to critically examine ELL services and make well-informed decisions about educating ELLs. [These leaders] understood that serving ELLs well would necessitate moving beyond comfortable, routine practices and, therefore, secured necessary resources and support to be able to make and sustain change. Ultimately, the leadership of these two principals created a rich environment for ELL achievement as it ensured social justice in education for ELLs.". [42] (p. 677)

Accomplishing this reform of ELL instruction required changes to the teachers' responsibilities; they were asked to redesign their approach to instruction so that it would serve ESL students in the context of a general education curriculum. Considerable professional development was provided to teachers to enable this change in their responsibilities.

A second study illustrating the importance of staff development opportunities [39] was conducted with school leaders in a rural Canadian district. The purpose of this study was to better understand how these school leaders developed authentic inclusive schools for students with exceptional needs such as autism and mild cognitive disabilities. Providing opportunities for the professional development of staff were among the two key factors leaders considered to be especially central to success (collaboration among key players in the students' education being the second). Professional development was identified as essential if inclusion was to be practiced effectively; it was viewed by leaders in the study as resulting in both determined and skillful teaching staff.

Provide support and demonstrate consideration for individual staff members. While the principal's support for individual staff members described by the evidence in this review seems applicable to many different goals and contexts, teachers initially struggling to achieve greater equity for their students may face especially significant challenges of both a personal (e.g., becoming aware of their own biases) and professional (implementing a culturally responsive curriculum) nature. Providing individualized support including individualized professional learning is likely to be especially important for such teachers.

Example. Consider the description of principal support provided by a teacher interviewed in one study [52]:

[The principal] tried to help people out that are struggling. He did this by suggesting teachers observe other teachers he knew to be strong in the area they were not, and by working with teachers individually. An eighth-grade teacher noted how [the principal] worked with teachers at the beginning of each school year... He expects [us to concentrate on reading across the curriculum] and he 
follows up with it, and he wants us to give him specific strategies of what we're doing and how we expect to push those children further. He meets with us to say, "What are you doing in your classroom? What do you think you should do, based on these scores, based on their achievement so far with you?" And I think that has a lot to do with it. [52] (p. 785)

This principal's support for teachers was not just professional. He was also attentive to events and challenges in his teachers' personal lives and helped when he could, recognized the good work of individual teachers, and created a sense of family among the school staff. Teachers were reported to be engaged in, and growing professionally, through the principal's provision of meaningful professional development, his demonstrably strong work ethic as well as the individual support he provided teachers.

Model the school's values and practices. Leading by example, or modeling, is associated with authentic and ethical approaches to leadership (e.g., [53,54]). Equitable school leaders "walk the talk"; they demonstrate, through their own behaviors and how they chose to spend their time, the values and practices they aim to also encourage throughout their schools as well as with the parents and local communities.

Examples. Two studies illustrate especially well what this could entail on the part of leaders aiming to foster greater equity. In the first of these studies [55], the third of four principals in the same school over a 20-year period was described as creating "a climate of success in part through leading by example, and by not holding teachers to standards she was not willing to demonstrate herself. She constantly reminded teachers "of the need to be grounded in the school's core values, particularly being student-centered and communicating high expectations." [55] (p. 306).

Evidence for the second illustrative study [56] consisted of a series of in-depth interviews with one African-American principal who helped boost the academic performance of mostly economically challenged African-American students in her school over a six-year period. The study aimed to "highlight the benefits of serving schools highly impacted by poverty through enacting transformative educational leadership rooted in critical care." [56] (p. 558). The leader in this case stressed the value of educators better understanding the reality of poverty in racialized and other oppressive contexts "so they can better prepare the most marginalized youth to achieve and succeed". She modeled the values she believed should guide the school toward a more caring environment for students and families partly captured in this excerpt:

Overall, the principal [Simms] repeatedly stressed her 'zero-tolerance' for uncaring teachers and those with deficit-based views of students regardless if they were middle class, white teachers with class and/or racial bias or middle class, or African American teachers with class bias. Simms pro- claimed, 'Even black teachers can come to schools with these type of misperceptions about the kids... Children don't ask to be born into this [poverty]!'. Simms also said she preferred to complete some community-based tasks herself vs. delegating them to a staff member and contended that such efforts should be a routine part of leadership. She maintained, 'I'm offended that I'm expected to put the social part of the job on the back- burner', referring to her offsite, community-based work. Simms indicated that she took professional risks at times to continue such activities. [56] (p. 566)

Build trusting relationships with and among staff, students, and parents. Evidence from the review indicates that trust among staff, students, and parents is an essential feature of productive relationships. Such trust depends on parents believing that the school has the interests of their children at heart and is willing to do everything it can to serve those interests.

Examples. The authors of one study [57] of nine schools serving Aboriginal students in Saskatchewan and Prince Edward Island describe how such trust was developed in those schools: 
From the view of the principals, the general thematic findings indicated that the principals' belief in students, emphasis on ensuring student belonging, promotion of relationships, and promotion of cultural relevancy of school experiences were seminal for Aboriginal students to have a positive school experience. [57] (p. 333)

Similar qualities were identified as helping build trust among schools and families including one study of Early Childhood Education leaders in New Zealand ([58]. As the authors explain:

These ECE leaders worked tirelessly to meet the needs of children and their families. As a result, strong connections developed with families that built cooperation and trust, and the comfort parents felt with teachers and teacher leaders (and vice versa) was obvious at all three sites. [58] (p. 92)

\subsubsection{Domain 3: Design the Organization to Support Desired Practices}

Build collaborative cultures and distribute leadership. Building collaborative cultures and distributing leadership is a key practice used by leaders who are successful in improving equity in their schools. Authentic collaboration and leadership distribution depends on strong beliefs about the value of collaboration and leadership distribution on the part of leaders along with open communication with staff, students, and parents.

... school leaders need to build a positive consensus around certain values: collaboration, openness in decision-making and trust and respect for individual learners... Such values are more likely to be sustained by distributed forms of leadership. [39] (p. 84)

Examples. One study [42] illustrating this enactment of this practice describes how two schools and their leaders went about creating inclusive ESL services by eliminating "separate, fragmented, and segregated instruction for students learning English". As the authors explain,

By not pulling out the ELL students from their general education classrooms, [the school leaders] dismantled the racially segregated grouping of the previous pullout-based ESL program and the fragmented and separate educational experience that went with it. They replaced it by bringing ESL methods and techniques to the general education classroom. [42] (p. 680)

The authors describe the approach these leaders took to the reform efforts as guided by their strong beliefs in both collaborative and democratic processes. Furthermore, these schools were ordinary elementary schools with strengths and blemishes. They operated in systems that were not designed for inclusive ESL and in bureaucracies that were generally not supportive of innovation. In spite of these potential barriers and real struggles, their successes demonstrate that this work is possible. What made it possible were the collaborative efforts between staff and administration, the communication between the school and ELL families, and the driving force of committed principals (p. 680).

A second study, illustrating how this leadership practice can be successfully enacted, was conducted with 16 principals in a Canadian rural district with a history of successful inclusive practices for students with exceptional needs [39]. This study aimed to capture the perspectives of school leaders about the implementation of inclusive education and the actions required by them to do so successfully. Collaboration was identified as necessary to the success of inclusion, although sometimes challenging to foster:

Three types of collaboration were described in the principal interviews: (a) communication with the parents; (b) collaboration within the school; and (c) collaboration with the community. Communication with parents was viewed as essential to student success. As one principal informed, [It's] very critical to have the parent. They have to really know what's going on, and have to approve it because they'll come back and say, 'Well, I didn't know that was going to happen.' The frequency of contact between parents of children with special needs and their teachers varied greatly. One family contacted the school staff on a daily basis 
while another family only communicated with school staff monthly. Overall, the school principals desired more contact with the parents. One principal expressed the concern that generally, though, it's a struggle even just to get a parent to come to an IPP meeting, really hard. [39] (p. 80)

Structure the organization to facilitate collaboration. While it is clearly important for school leaders to create structures that encourage collaboration, the types of structures described by the studies included in the review did not seem unique. More than a third of the studies describing structures put in place by leaders to foster collaboration for equity identified staff teams - most would qualify as "professional learning communities" —as the structures.

Example. The teams developed by leaders included in a study by Theoharis and O'Toole [42] were a means of distributing leadership and fostering collaboration as well as encouraging co-teaching, an innovation aimed at significantly increasing culturally responsive instruction by larger proportions of staff.

The principal whose equity work with second language students was the focus of a second study [42] explained that in his school:

Teams were created for each grade level consisting of one or two teachers at each grade level paired up with an ESL teacher. These teams worked together to co-plan and co-teach all of the students within their classrooms together. Most of the teams were formed autonomously; in cases where team members did not step forward, I met with teachers to decide on how best to create teams. [42] (pp. 669-670)

As the authors of this study explained, "over the time we studied [the school], in the case of both autonomously created groups and those formed under the guidance of [the principals], some teams developed into lasting partnerships, whereas others opted to reconfigure their teams at the end of the year. This approach to teaming as a strategy for improving collaboration in the interests of equity in schools is echoed in other studies in the review, as is the engagement of parents on some school teams [46].

Build productive relationships and connections with families and communities. More evidence was provided by studies in the review about the nature and importance of this practice for equitable leadership than any of the other 22 practices in the guiding framework. Results indicate that improving equity in schools serving racially and culturally diverse students, in particular, requires leaders to forge strong bonds between schools and families. Such bonds are typically nurtured through good communication.

Examples. Principals in the rural district sampled in a study by Irvine et al. [39] stressed the importance of communication and collaboration with parents, staff, and community. Another study [42] described forms of communication between schools and families purpose-built for groups of Spanish and Hmong families who had never had communication with schools in the past. As the principal of the school explained:

Our communication involved (a) a plan to have schoolwide notes and information translated or relayed to families, (b) arranging conferences with Hmong- and Spanish-speaking families at each marking period to discuss student progress, and (c) sending recorded messages to Spanish- and Hmong-speaking families in their home languages using the automated phone system.... We got a lot of very positive feedback from our [ELL] families. They loved that were had much better communication. They loved the quarterly conferences, and they expressed their appreciation for their children being integrated and an authentic part of their elementary classrooms. [42] (p. 673)

A second part of this leadership practice is to help connect families and schools to the larger community of which they are a part. Underserved students and families are often unable to access the community resources (e.g., housing, health care, social services) they need in order to realize the opportunities potentially available to them in the school. To illustrate, the two leaders in one study "developed a broad vision for school and community, 
positioned the school as a physical asset which the community could use for purposes other than schooling (e.g., sites for provision of health care, workout facilities) and championed community causes at the school" [44] (p. 679).

"Community organizing" is a label used for a significant part of the leadership aimed at building productive relationships between schools, families, and communities in the interests of greater equity. This approach aims to build the motivation, capacity, and social capital needed by low-income and/or ethnically diverse parents and other community members so that they are better able to influence school decisions on behalf of their children, collaborate with others in the process, and hold schools accountable.

Two studies included in the review provide more detailed illustrations of how school leaders contributed to the success of initiatives explicitly framed as community organizing. One of these studies by Ishimura [46] was conducted in three small autonomous schools which had been part of a larger community organizing initiative for about four years at the time of the research. The larger initiative had provided a considerable amount of training to the principals in the three schools. These principals contributed most directly to the success of community organizing by building strong, trusting relationships with staff and parents as well as by distributing and developing the leadership of both staff and parents involved in the initiative. Principals also helped parents better understand the teachers' perspective on the schools' curriculum and instruction; develop a sense of collective power to influence school decisions; and further their abilities to challenge the status quo in the schools and district when necessary.

Evidence for the second study by Khalifa [59] illustrating leadership for community organizing was conducted in one small alternative high school serving about 100 students. Most of the school's students were African-American, as was the principal who had led the school for 33 years and had taught some of the parents, and grandparents of the current students. This principal was both responsive to and an advocate for community concerns, often helping to connect members of the community with formal institutions and the additional resources they provided. His interactions with students and parents reflected his deep understanding of their culture and concerns, with such interactions occurring not just in the school but through the sometimes-unannounced visits he made to the homes of his students. He pushed back against low expectations for student success when he encountered it in teachers, parents, and students themselves. He was a strong advocate for community causes and encouraged his staff to engage in such advocacy. Teachers with exclusionary beliefs and practices were confronted and/or mentored by him.

This principal's race and longevity as school leader helped to generate a level of trust in him on the part of students, parents, and other community members that would be hard to replicate for many school leaders. Nonetheless, his leadership provides insights about community organizing done by a master with unflagging optimism about increasing equity for his students and their families and unlimited persistence in his pursuit of that goal.

Maintain a safe and healthy school environment. The contribution of this practice to the success of most students, but especially students who struggle at school, is well documented far beyond the research sampled in this review. This research can be dated to studies of "effective schools' published in the 1970s. Marzano's [60] review of research about "What Works in Schools", for example, identified a safe and orderly/healthy environment as one of five key features of effective schools, and leadership is typically required if this feature of schools is to be developed and maintained.

Example. Some of the research in this review, while endorsing the contribution of this practice to more equitable student outcomes, adds the importance of also ensuring that students' feel a sense of belonging in the school. By way of illustration, three of the principals included in one Canadian study [57] of leadership in schools serving Aboriginal students explained their views on this as follows:

Two-Paths believed that his role in assisting Aboriginal students is to create a school culture where students feel they belong, because, in doing so, they want 
to contribute to the learning process. On this point, he said, 'When students develop that sense of identity, that sense of belonging, they're going to be much more engaged in the school generally, and much more committed to being here'. Holds-Ropes indicated, 'When I see a kid from [name of First Nation community], one of the first things I do is introduce him to the soccer coach and track coach, because soccer and track are huge [in that community]'. Strong-Wrestler found that 'inspiring our students to belong to the learning' was an important feature of his role of school leader. [57] (p. 335)

Students' sense of belonging was fostered by a climate of care [61] and inclusion [62] in their schools.

Acquire and allocate resources in support of the school's vision and goal. Evidence in the review attributed considerable importance for leaders aiming to improve equity in their schools, to finding the resources needed to meet the needs of underserved students, and to aligning the allocation of those resources with the schools' efforts to improve equity. It does not require much research to appreciate the importance of aligning resources with equity goals. In some education systems, schools serving the least well-served students find themselves with the least experienced and qualified teachers [63], the least stable school leadership [64], the poorest facilities [65], and circumstances that make it very difficult for both parents and communities to authentically partner with their children's schools [21].

The alignment and allocation of teachers and school-level leaders is the most critical of the resources available to improve equity in schools. The alignment and allocation of these two key resources, however, is shared between school and district-level leaders, at least in systems with district structures.

Example. Ladd's [66] high-quality quantitative study found that a significant condition for the retention of experienced teachers in schools serving large proportions of economically challenged African-American students was the quality and stability of principals, something very much influenced by district decisions. As the author explains:

Among the working conditions [influencing teachers' retention decisions] by far is the quality of school leadership ... These findings are fully consistent with a transformational model of school leadership ... that includes not only support for teachers but also a shared vision, a trusting environment, and effective processes for making group decisions and problem, solving. [66] (p. 256)

Retaining experienced teachers, perhaps the most important resource available for improving the success of underserved students, depends on districts allocating their best leaders to schools serving such students for significant periods of time. Studies by Klar and Brewer [52] and by Okilwa and Barnett [47], illustrate the lengthy duration of principal tenure common in schools successfully improving equitable outcomes for their students. These leaders also enact many of the transformational leadership practices included in the guiding framework.

\subsubsection{Domain 4: Improve the Instructional Program}

Staff the Instructional Program. Evidence from the review about how this practice is enacted by equitable leaders overlaps and extends findings discussed above about the importance of aligning school resources with school priorities. The challenge for equitable leaders in staffing the instructional program is not just the recruitment of suitable teachers, but also their retention.

Evidence included in this review confirms the widely understood importance of leaders staffing their schools with people who have both the professional capacities needed to further their school's curricular goals as well as the personal characteristics that help to ensure those goals are furthered with the diverse range of students served by many schools.

Examples. Demie's [36] study, conducted in eight primary and six secondary schools in one of London's most ethnically and linguistically diverse boroughs, provides especially compelling evidence about this leadership practice. The economically disadvantaged, Black 
Caribbean students in these schools had made significant progress in their achievement over a half dozen years, progress much greater than was made by similar students in the borough's other schools. The interview, observation, and focus group data collected in this study pointed to the success school leaders had in attracting many staff with demographic profiles similar to the students.

In the long run, retaining the right teachers is just as important as attracting them to the school in the first place. Preferences about the "ideal school" in which to work vary considerably across teachers. Some realize their greatest professional rewards from working with high achieving students, often from privileged families, where the content of their teaching discipline or subject prevails over most other concerns. Other teachers found that their greatest satisfaction came from helping students challenged in some way to succeed; this was their "calling". Misalignment of schools and teacher preferences for their ideal school is a significant cause of teacher turnover and excessive teacher turnover has a well-documented negative effect on student success $[67,68]$. As has already been noted, teacher retention is a significant challenge for school leaders aiming to increase equity for historically underserved students.

Viano et al.'s [69] recent study offers specific advice to leaders about how to improve the chances of retaining teachers likely to be of considerable value in advancing a school's equity agenda. This methodologically robust, quantitative study included a large number of teachers who professed a preference and willingness for working in low-performing and turnaround schools. School features with the greatest impact on these teachers' decisions to stay at their school included consistent enforcement of discipline and administrative support, school safety, small class sizes, and the availability of high-quality PD. As the authors suggest, leaders should use these findings to help recruit and retain teachers who have shown a willingness to teach in lower performing and turnaround schools.

Provide instructional support. Studies in the review providing evidence about the enactment of this practice, with equity in mind, described a variety of mostly well known, contextually dependent, forms of support. These forms of support included, for example, close supervision of teachers who are insensitive to the biases embedded in their relationships with students, directing teachers to professional development useful in responding effectively to the challenges they are facing in better meeting the needs of minoritized students [70] and ensuring that culturally relevant curricula are being implemented [57].

Examples. Several studies take a step further, however, by not only describing the type of curriculum that leaders should help staff implement but also the nature of the pedagogy teachers should use when implementing such curricula. Teachers' pedagogy may be at least as important a focus as curriculum for those leaders working in the many education systems that now have centrally developed curriculum policies that schools and their leaders are expected to implement. Such implementation is increasingly understood to be a form of mediation [71], which will often entail helping teachers interpret policy expectations and shaping the priorities the school gives to different features of the policy.

As part of their mediation, school leaders are able to enhance equity in their schools by making sense of, and implementing, policies with the collective interests of underserved students in mind [72]. A key method for reflecting those collective interests will be to encourage the implementation of central curriculum policy using forms of pedagogy that encourage the learning of many groups of underserved students $[40,73,74]$, in addition to most other students. Such pedagogy features the active engagement of students and is culturally responsive [75], carefully scaffolded, constructivist, often aimed at developing deep understanding [76-78] and helps to ensure that the curriculum is clearly relevant to students. Providing support to teachers implementing these forms of pedagogy is a significant addition to what it means, typically to provide instructional support.

Monitor student learning and school improvement progress. Using the best available evidence to monitor progress is good advice for most school leaders regardless of their context. When that context includes concerns about equity, it is useful to separate concerns about equitable outcomes from concerns about equitable educational opportunities. 
Educational policies enacted by many provincial, state, and national governments aim to improve equitable outcomes for students through large-scale testing programs that require districts and schools to break out results in categories including student race and SES, for example. Notwithstanding the limitations associated with some of these testing programs, viewed over time, such disaggregated data provide hard-to-avoid indications of the equity progress being made by districts and schools. Leaders aiming to improve equitable outcomes in their schools make skilled use of these data. These data also serve as tools in helping to meet external demands for accountability.

Data about equitable educational opportunities-conditions in schools with effects on student learning - are typically not nearly as accessible, or at least as systematic, as data about equitable outcomes, even though equitable opportunities are the proximal goals to be accomplished if the distal goals are to be achieved. Excerpts from two studies illustrate how some successful equity leaders use data to monitor progress in their schools.

Examples. Okilwa and Barnett [55] illustrates how one principal used test data about student achievement as well as attendance data to successfully advance equity in her school:

Principal Robinson started the interview by showing us some of the school's academic and attendance data over the past two years. Ms. Robinson suggested that analyzing data to provide services to students commensurate with their needs, particularly "high priority kids" is critical. She pointed out that constantly examining data was particularly crucial given the high student mobility rate of 34 percent. Students were always enrolling in and leaving [the school], some of whom did not have personal records on hand upon entering the school ... In addition, teachers reiterated that they spend time disaggregating the data in order to make instructional decisions. To reinforce the utility of data [one teacher] said, "we are working with Lead Forward. We are breaking down that data. We are looking at our focus standards or process standards and what we need to do.". [55] (p. 310)

Data about the equity of educational opportunities a school provides its students is not just less available from external sources, it must also reflect the multiple and complex ways in which schools and their staff influence the equity of the educational opportunities provided by the school. Equity of opportunities can be influenced in fairly obvious ways, for example, by the nature of school structures, the curriculum. and how the curriculum is implemented by teachers in classrooms. Less obvious, but just as important, are the biases some staff may exhibit toward their students, the extent to which struggling students feel that school staff care about them, and the sense of physical and psychological safety experienced by students in school.

An excerpt from Klar and Brewer [45] illustrates how one leader who was successful in advancing equitable outcomes in his rural school over a seven-year period went about collecting the wide array of highly sensitive evidence required to monitor the opportunities his school were providing and to actively disrupt and resist sources of bias where they were found. While the type of monitoring this principal engaged in is by no means unusual, focusing attention on the equitable or inequitable nature of what is observed is what provides the depth and range of data required to especially mitigate the subtle sources of inequity and resist dysfunctional practices and attitudes when they surface. Teachers describe the principal' approach to monitoring as follows:

[Principal Cummins] continually monitored school activities. Describing him as "always in the hallways," an eighth-grade teacher reported, "He's very accessible to us and to the students, and that makes a big difference." In addition to being visible in the corridor, Cummings also regularly visited classrooms. Cummings, the assistant principal, and the instructional coach also regularly reviewed lesson plans and formally visited classes. An eighth-grade teacher described the type of feedback teachers received after classroom visits. She stated, "they make positive comments on things they'd like to see more of. Or if we're trying 
something new, they'll say, 'Let me know how that goes. I'd be interested to hear that'." This teacher also reported that Cummings frequently asked, "Where do you want the children to be at the end of this activity?". [45] (p. 436)

Two other studies in the review $[79,80]$ also provided evidence about the value of providing both formal and informal opportunities for students who feel marginalized by their school, to share their opinions about how well the school is or is not serving their needs, and what might be done to improve the contribution the school is making to their development. These actions contribute to trusting relationships between students and staff, provide the school with a uniquely valuable perspective on the value of teaching and learning for underserved students in the school, and produce useful evidence about progress toward achieving the school's equity goals. As Mitra [80] explains:

Student voice activities can create meaningful experiences for youth that help to meet fundamental developmental needs especially for students who otherwise do not find meaning in their school experiences. Specifically, this research finds a marked consistency in the growth of agency, belonging and competence, three assets that are central to youth development. [80] (p. 651)

Buffer staff from distractions to their work. Teachers potentially face many immediate distractions to their instructional work with students. On a daily basis, examples of these distractions can include school announcements over the PA system, time required in class for various fund-raising activities, and requests by special interest groups to speak to their students. Less immediate but significant potential distractions can include, for example, requests by the province or the district to implement practices clearly not suitable for a teacher's students. School leaders increase the time in class devoted to meaningful instruction by minimizing the potential distractions potentially encountered by their teachers.

Example. The principal included in a study carried out in Tasmania was known for 'buffering the staff and students from anything that did not fit her and the school's clearly articulated and communicated objectives" [81]. An example of this was when she and her school refused to be part of a system project that would have been a distraction from what they were already doing.

While the empirical evidence in support of this practice was sparse, several reviewers of a draft of the paper stressed its importance. As one Ontario director of education noted:

A crucial [practice] in my mind is Buffer staff (and School) from Distractions to Their Work. It seems like everyone wants a piece of the schools to promote good, well-meaning priorities. We have found if schools fall to this, student learning will not improve. Districts have to give permission for leaders to have a laser focus (Personal communication).

Participate with teachers in their professional learning activities. This practice has been widely endorsed for school leaders largely as a result of findings reported in the meta-analysis by Robinson et al. [82]. While none of the studies in this review mention this practice in relation to equitable leadership, the evidence reviewed in Robinson's meta-analysis was from large-scale quantitative studies of the type reviewed later in this review. These are studies of successful leadership practices conducted in studies using, as dependent variables, the acquisition of some sets of desirable outcomes by large proportions of students traditionally underserved by schools. Based on such evidence, this practice has the potential to help improve equitable student outcomes in schools.

Example. One of the few studies that did touch directly on this practice was conducted in two schools working to provide more inclusive ELL experiences for their students [42]. As one interviewee explained, the principal in one of these schools (where the vast majority of students spoke either Spanish or Hmong) did not begin her ELL equity work with any special knowledge about either her students or the nature of effective, equitable ELL programming. However:

[Principal Lea] worked to gain her own knowledge about valuing home language and cultures, about connecting with families in respectful and meaningful 
ways, and in aspects of good ESL instruction as well as language development." She did this through her own graduate work in educational leadership, by engaging in study groups with principals about ELLs, and by participating with her staff in professional development on ELL conducted by university faculty. [42] (p. 660)

The second principal in this study had considerable knowledge about ELL instruction at the outset. Nevertheless:

Principal Luke worked with the entire staff and, in a more concerted effort, with the school improvement team to understand the realities of the programming for ELLs and other students who were traditionally marginalized. [42] (p. 668)

This excerpt illustrates the importance of leaders, aiming to improve equity in their schools whatever the source, in developing extensive knowledge about the language, cultures and other aspects of their students' families and doing so, whenever possible, with their staff.

\subsubsection{Domain 5: Securing Accountability}

Build staff members sense of internal accountability. The purpose of this leadership practice, when it is enacted to improve equity, is to have all staff members consider themselves personally responsible, along with their colleagues, for implementing practices and relationships with students and their families that are anti-oppressive, respectful of the funds of knowledge students and their families bring to the schools, and which contribute to equitable outcomes for students. Building staff members' sense of internal accountability is usually an extended process that requires leaders to provide ongoing opportunities for more deeply understanding the school's equity vision, collaborating with colleagues about how best to meet the student needs related to that vision. Equitable leaders provide teachers with the time and other forms of support they need to further develop an appreciation of their responsibilities.

Example. Okilwa and Barnett's [47] study of a Texas high needs school that sustained its students' high performance over a twenty-year period found that the staff's sense of collective responsibility for the achievement and welfare of their students was one of four factors accounting for the school's sustained success. Describing the orientation of the first of the four sets of leaders at the school (excerpted from a U.S. Department of Education report):

[The principals and vice-principal] inherited a disjointed faculty. To counteract this isolation, Ms. Williams and Ms. Peterson initiated structures to ensure collaboration among faculty. Time and space were created to facilitate collaboration. Teachers began to "plan together and share ideas and resources. They [visited] each other's classrooms, observed, asked questions, and advised one another about their teaching practices" (p. 43). A sense of collective responsibility emerged as "every teacher had a stake in each child's success, but also, they had a stake in every other teacher's success" (p. 51). The leadership team supported this value by frequently and purposefully scheduling faculty brainstorming and problem-solving sessions. By spending more time together, teachers became "closer than ever before [and became] more open and honest with one another thus creating stronger bonds of collegiality and collaboration. [47] (p. 51)

Meet the demands for external accountability. Few studies included in the review provide evidence about the efficacy of this leadership practice in helping to achieve more equitable schools. As discussed earlier, however, many governments have introduced an accountability mechanism driven by testing systems accompanied by requirements for districts and schools to report test results disaggregated by categories of students reflecting common sources of inequity such as socio-economic status and race. Every state and province in North America now has such a testing system [83]. However, some evidence indicates that school leaders need considerable support to use these test results 
effectively [83]. Equitable leaders enact this practice by balancing their school's focus on state-wide test results with additional data about progress in achieving the more specific goals and priorities established with their staff, students, and parents in their schools.

Examples. Gurr et al.'s [43] study of three improving Australian schools considered the political context faced by school leaders when trying to meet system expectations on national literacy and numeracy test performance. While all three schools understood the importance of meeting such expectations, they were more interested in other matters such as developing life-long learning or using more diagnostic tests of learning to help improve teaching and learning. The principals knew how to balance system and school needs:

Through paying attention to key measures of student learning, and broader measures of success, the leaders navigated and balanced the political contextual factors by selecting and focusing on achievement results in ways that strengthened the schools' re-establishment as viable, innovative and student-centered.

[43] (p. 30)

Large-scale tests can be used by school leaders to move their schools' equity vision forward, however. As Klar and Brewer [52] found, unexpected evidence of poor student performance on such tests can energize leaders to establish new goals and higher expectations for their schools as well as doubling their efforts to help teachers provide instruction better suited to students who are struggling with the school's existing instructional practices.

In sum, there seems good reason to conclude that Meeting the Demands for External Accountability, using the tools described here, is a practice with the potential for improving equity in schools when enacted by leaders who are able to interpret large-scale test results accurately, locate, and use evidence about progress with school-based priorities and adequately support staff in using these several types of results for instructional improvement.

\subsection{Section Two Results}

\subsubsection{Large-Scale Quantitative Studies with Evidence of Outcomes}

One component of the review search strategy, specifically aimed at identifying relevant large-scale quantitative studies, produced ten such studies, nine conducted in the U.S. and one in England. These were studies of leadership effects on several types of student outcomes and six of these studies included mediating variables in their designs. Eight of the studies used cross-sectional designs and two used longitudinal designs [32,84]. While none of these studies explicitly claimed to be focused on "equitable" leadership, the dependent measures (e.g., student achievement, classroom participation) in all studies came from a high proportion of students who would typically be considered "underserved":

- Seventy-seven percent of students from whom data were collected in the Adams et al. [85] study qualified for the U.S. federal lunch program; $85 \%$ were eligible for a free or reduced-price lunch rate, and 73\% identified as an ethic minority.

- Schools serving high proportions of low SES students in England encompassed the students included in the three-year mixed methods study reported by Day et al. [32].

- State achievement data were collected for all elementary students in the 81 schools included in the study by the Author and Colleagues [18]. About $50 \%$ of these students were economically disadvantaged and 15\% were English language learners.

- Of the students enrolled in sample schools included in the three-year study by May et al. [24], 74\% were from a minority race group, $29 \%$ were eligible for free or reducedprice lunch, and 2\% had limited English proficiency. Variation in school-level demographics was substantial, ranging from $24 \%$ to $100 \%$ minority.

- All five studies reported by Sebastian and his colleagues [86-90] used several forms of achievement data from Chicago public schools with a student population of about $50 \%$ African-American, 38\% Latino, 9\% White, and 3\% Asian. Approximately $85 \%$ of these students were eligible for free or reduced-price lunches.

- Of the students sampled in Yoon's [91] study, 88\% were minorities and 76\% qualified for free or reduced lunch. 
Two of the ten studies $[18,32]$ explicitly conceptualized and measured all, or almost all, of the leadership practices included in the guiding framework, while five additional studies included measures that were similar although less extensive. For example, items included in Sebastian et al.'s [90] study measured the extent to which principals:

- Make clear to the staff his or her expectations for meeting instructional goals;

- Communicate a clear vision for our school;

- Set high standards for teaching and for student learning;

- Know what is going on in classrooms;

- Understand how children learn;

- $\quad$ Press teachers to implement what they have learned in professional development.

Although worded slightly differently, all but the last of these practices are encompassed in the review framework.

By virtue of their research designs, these studies are unable to identify possible adaptations to the leadership practices they measure as a means of furthering equity goals, in particular. However, results of these studies do add to the evidence originally used to portray the guiding framework leadership practices as "core", that is, as practices basic to the success of school leaders in fostering student success in their schools across the many different contexts in which leaders find themselves.

One of the large-scale studies [89] examined the relative contribution to the successful leadership of a selected set of instructional leadership practices as well as a selected set that the study labelled "organizational management skills" as identified in an earlier study [92]. This leadership-management distinction is inconsistent with the definition of leadership used by the guiding framework ("the exercise of influence on organizational members and diverse stakeholders toward the identification and achievement of the organization's vision and goals." (for more on the leadership-management distinction, see Leithwood [93]). Nonetheless, results of this study as well as its predecessor, suggest that these skills or practices contribute at least as much to the school leaders' effects as instructional leadership practices. In addition, this study concluded that it is the combination of these two sets of practices that have the greatest impact. The instructional leadership practices tested in this study included:

- Using data to inform instruction;

- Developing a coherent education program;

- Using data for program evaluation;

- Improving teachers' practice through formal evaluations;

- Coaching teachers;

- Implementing effective professional development;

- Effectively integrating supplementary after-school or summer programs.

All but the last of these practices, differently worded, are subsumed by practices in the guiding framework. The last of these practices does seem intended to improve outcomes for typically underserved students and might be included as part of developing a more equitable and coherent instructional program.

Organizational management practices (conceptualized here as an additional set of leadership practices) tested in this study included:

- Developing and monitoring a safe school environment;

- Dealing with staff concerns;

- Managing budgets and resources;

- Hiring personnel;

- Managing personal and school related schedule; and

- Maintaining campus facilities.

Two of these practices are already part of the guiding framework (Developing a safe school environment and Staffing the instructional program) while the remainder are not. Three of these remaining practices include the term "managing", a commonly used term with an entirely opaque meaning. 
Finally, the study by May and colleagues [84] reported results very similar to a portion of the results also reported by Day and colleagues [32]. As May and colleagues concluded:

School leadership is driven not only by the principal's pre-existing philosophy about schooling and desire to change a school in certain ways but also by the principal's reaction to conditions in the school, which may change from year to year. It is also possible that principals in lower performing schools are forced to be more reactive more often to the schools' current circumstances than principals in higher performing schools. This may explain why principals from lower performing schools in our study spent more time on instructional leadership activities. This would suggest that the job of a principal may often be more reactive than proactive". [84] (p. 433)

\subsubsection{Reviews of Research without Evidence of Outcomes}

Results of six recent reviews of research are summarized in this section. While most of these reviews identified some of the practices and dispositions included in the framework, the main focus of this section was on the practices and dispositions not included. In most cases, these are practices and dispositions based on both theory and (mostly descriptive) empirical evidence.

Furman [33]. This review identified two sets of equitable or socially just leadership practices. One set was culled from the analysis of 14 empirical studies. All but several of these studies conformed to the design of the "descriptive" category of studies in this review; often rich qualitative data have been collected about the practices and dispositions of small numbers of leaders identified as working for social justice schools but no evidence has been provided about the association between those leadership practices and dispositions and some desirable set of student outcomes.

The practices identified by these 14 studies include suitable adaptations of many practices and dispositions included in the guiding framework. Practices not part of the guiding framework identified in this set of studies include:

- Being a "critical activist";

- Fostering a collaborative and democratic dialogue;

- Having an open-door policy;

- Developing one's own resistance and coping strategies;

- Exercising social control with purpose;

- Advocating for the rights of diverse students and their families; and

- Being caring and encouraging.

Dispositions identified in the 14 studies not part of the guiding framework include:

- Courage in the face of community and accountability pressures;

- A deep, lifelong commitment to social justice and a strong sense of purpose;

- A personal sense of "being right" but humble about one's accomplishments;

- A tenacious commitment to justice.

Furman's review also includes a theoretical conception of social justice leadership from which she infers both equitable leadership practices and dispositions. Labelled the PraxisDimensions-Capacities Framework, this conception posits four sites in which leaders should work for social justice, the personal, interpersonal, communal, systemic, and ecological, and infers what socially just leaders should do in each dimension. Across the four dimensions, practices not included in the guiding framework include:

- critical reflection to explore one's own values, assumptions, and biases in regard to race, class, language, sexual orientation etc.;

- build community across cultural groups through inclusive, democratic practices;

- assess, critique, and work to transform the system, at the school and district levels, in the interest of social justice and learning for all children;

- recognize structures that pose barriers to students' progress and create proactive structures and systems of support for all students"; and 
- $\quad$ act with the knowledge that school-related social justice issues are situated within broader sociopolitical, economic, and environmental contexts and are interdependent with broader issues of oppression and sustainability. Reflection in this dimension includes an awareness and understanding of these relationships and of the school's role in addressing these broader issues.

Dispositions not part of the guiding framework include:

- Self-knowledge through critical reflection;

- Knowledge of others, especially students from diverse cultural backgrounds.

Scanlan \& Lopez [94]. Concerned with leadership practices that advance the success of culturally and linguistically diverse (CLD) students, results of this narrative review were based on an analysis of 79 peer-reviewed studies, reviews, and conceptual analyses. The review was guided by a theoretical model combining three dimensions of languageoriented quality schooling (language proficiency, quality curriculum and instruction, and sociocultural integration) and four areas of equitable language development (the location and arrangement of services, access to high-quality curriculum, and funding and policy mechanisms).

Notably, for purposes of the present review, there was no theory or model of leadership embedded in the conceptions guiding this review. Educational conditions identified by research on how to foster language acquisition on the part of CLD students were the primary focus of the literature reviewed; the practices and dispositions of successful CLD teachers and (especially) school leaders were inferences drawn by the authors of the review from this literature. While these inferences aim to ensure equity for CLD students, in particular, they conform to three generic leadership practices equitable leaders use regardless of the source of inequity: ensuring a high- quality curriculum, meaningful approaches to pedagogy, and inclusive organizational structures:

\section{High Quality Curriculum}

- Ensure students have access to high quality curriculum;

- Chooses from among available models for cultivating language proficiency, the model best suited to the school's students and families (the knowledge required to do this might be included in the cognitive category of leadership dispositions).

High Quality Instruction

- Assist staff in developing a linguistically responsive pedagogy;

- Recognizes language as an asset and helps staff build on the linguistic heritage of CLD students;

- Helps staff avoid essentializing the conversational-academic dichotomy in language learning;

- Provide staff with professional development about ways to integrate content and language instruction;

- Support students to succeed in academic settings.

Inclusive Organizational Settings

- Help teachers build their CLD students' sense of belonging;

- Ensure CLD students are included in classrooms with opportunities to fully participate in as wide a range of English for academic purposes as possible;

- Provide opportunities for interaction between CLD students and their native English classmates.

Ishimura \& Galloway [25]. The purpose of this review, as the authors explained, was to "contribute to our understanding of leadership for equity by proposing a conceptual framework of equitable leadership practice, grounded in the research literature and aligned to the national ISLLC standards". Evidence for the review combines the substantial research done to produce the widely used U.S. Interstate School Leaders Licensure Consortium 
(ISLCC) leadership standards initially, along with a subsequent "expert convergence" study that asked a panel of 40 expert participants, "for each standard, what the most important practices would be if their core goal was addressing inequities and improving schools for those who have not been well-served due to their race, ethnicity, class, home language, or other group identity". The findings of the expert convergence study were then merged with the results of the authors' review of literature on socially just, culturally responsive leadership.

A group of ten "high leverage" leadership practices was the outcome of this process. These were practices for improving equity among students who have not been well served by schools for reasons of race, class, ethnicity, home language, and special needs. Of the ten practices resulting from this work, the core version of eight are already included in the guiding framework. Described much more fully in the paper, these practices include:

1. Constructing and enacting an equity vision;

2. Supervising for equitable teaching and learning;

3. Developing organizational leadership for equity;

4. Fostering an equitable school culture;

5. Allocating resources;

6. Hiring and placing personnel;

7. Collaborating with families and community;

8. Modeling.

The two practices that are not yet part of the guiding framework are as follows:

Engaging in self-reflection and growth for equity

Leadership engages in personal and intellectual work to understand how privilege, power, and oppression operate-both historically and currently-in schools and society. As part of this process, leaders examine their own identities, values, biases, assumptions, and privileges. This includes defining core values around democracy, social justice, and equity; having the will to act; taking risks to put themselves on the line; and modeling continuous learning and inquiry in the pursuit of equity. Leadership continually asks: Who are we serving/not serving and why? Who is being included/excluded and how? [25] (p. 134)

Influencing the sociopolitical context

Leadership collaborates with teachers, parents, community members, unions, and other organizations and coalitions to address the roots of systemic inequities by publicly advocating, creating, and influencing equitable and socially just policy and implementation. Those in formal leadership roles (e.g., principals) strategically use their power and authority within the system and act as allies to educators, students, and parent/community leaders in prioritizing policies and systems to ensure a high-quality education for every student. [25] (p. 135)

Capper [95]. This review aimed to determine how critical race theory (CRT) can inform approaches to leadership that are likely to eliminate or at least reduce racism. Sources selected for the review were published articles and book chapters applying CRT to formal leadership positions in preK-12 education.

Results of the review identified six interrelated "tenets" of CRT and describe both explicit and implicit implications for leadership associated with that literature. This summary identifies and defines the six tenets (these definitions are direct quotes from Table 1, p. 795 of [95]) and the leadership practices and dispositions associated with each tenet.

Tenet 1: Permanence of racism (Racism, both conscious and unconscious is a permanent component of American life). This tenet is associated with one leadership disposition and three practices. Leaders guided by this tenet:

- develop their own anti-racist identity (a disposition);

- engage in informal individual conversations and whole faculty conversations about race with their faculty when race-related issues arise in the school;

- model this process with staff; 
- conduct equity audits (collect and analyze race data, develop concrete goals, implement plans to eradicate race, measure progress and be transparent with the community).

Tenet 2: Whiteness as property (Because of the history of race and racism in the United States and the role U.S. jurisprudence has played in reifying conceptions of race, the notion of Whiteness can be considered a property interest). Leaders guided by this tenet:

- anticipate, understand, and respond to the fierce backlash they will experience from White middle-/upper-class families-including liberal families (p. 795) protecting their property interests when leading equity work.

Tenet 3: Counter storytelling and majoritarian narratives (A method of telling a story that aims to cast doubt on the validity of accepted premises or myths especially ones held by the majority; majoritarian narratives are also recognized as stories and not assumed to be facts or the truth). This tenet is associated with many leadership practices. Some are included in the guiding framework in a general form and seven seem especially practical. Leaders should:

- ensure that individuals and communities of color are authentically included in democratic decision making about strategies and plans to eliminate racial inequities [95] (p. 810);

- $\quad$ seek the perspectives of students, families, and communities of color and make public their stories, views, and examples of how the current system is not working for them;

- conduct focus groups with students of color and involve students of color in demographically proportional ways in school decision-making teams that include students;

- hire educators of color;

- create working conditions for these educators to thrive and be genuinely mentored into leadership positions;

- ensure district and school decision-making teams are racially representative of the school community [95] (p. 811);

- are deeply engaged in the school's community and families of color.

Tenet 4: Interest Convergence (Significant progress for Blacks is achieved only when the goals of Blacks are consistent with the needs of Whites). Leaders guided by this tenet should:

- frame their work in such a way that middle- and upper-class Whites in the community will also benefit.

Tenet 5: Critique of Liberalism (Critique of basic notions embraced by liberal ideology to include color blindness, meritocracy, and neutrality of the law). Leaders guided by this tenet should:

- identify the full range of races and cultures in their school communities;

- reach out to families and students, recognizing their assets and value to the school and their unique needs;

- $\quad$ help staff recognize the ways the school, its culture, and practices are not race neutral and reflect White culture and the ways they expect students of color to assimilate and blend into the school;

- ensure that the school's curriculum, culture, structure, and policies reflect the racial diversity in the school;

- challenge and eliminate racist assumptions wherever they are encountered;

- be critical and discerning about equity policies and practices to ensure that these policies and practices do not perpetuate racial inequities.

Tenet 6: Intersectionality (Considers race across races and the intersection of race with other identities and differences). The implications for educational leaders of this tenet are extraordinarily ambitious, suggesting that educational leaders support and participate in efforts to not just eliminate racism but other forms of subordination such as gender, class, and sexual orientation. As ambitious as it is, this broader mandate for educational leaders is a normal part of the job when it is limited to education within the leader's school and 
district. Many schools serve students challenged by multiple sources of inequity-not only gender, class and sexual orientation, but also ethnicity, religion, dis/ability, and language and more.

As the review acknowledges, scholars and practitioners of culturally relevant pedagogy, for example, do not generally consider students with disabilities. Therefore, equitable leadership practices must concern themselves with more than the elimination of racial inequities. To reflect this wider set of responsibilities, leaders should:

- learn how to provide equitable leadership across the full range of student differences in their schools;

- identify and implement policies and practices that are appropriate for the full range of students served by the school.

Khalifa et al. [26]. Using empirical evidence published between 1989 and 2014, this review aimed to describe the practices or behaviors associated with Culturally Responsive School Leadership (CRSL) enacted primarily by urban school-level leaders in order to "understand, respond, incorporate, accommodate, and ultimately celebrate the entirety of the children they serve-including their languages and literacies, spiritual universes, cultures, racial proclivities, behaviors, knowledges, critical thought, and appearances"(p. 1278). Results of the review were intended to be limited to leadership practices that evidence suggested "had a direct impact on school climate, curriculum, policy, pedagogy and student achievement" [26] (p. 1276).

Because the framework for the review acknowledged some of its roots in research about both instructional and transformational leadership models, as with the guiding framework, a significant number of the CRSL practices identified by this study encompass core versions of the practices included in the guiding framework. These practices include, for example, creating a vision and specific goals, building trusting relationships, creating a sense of community, fostering strong relationships between schools and families, and staffing the instructional program.

The 32 leadership practices identified from evidence in the review were classified into four major strands of CRSL: Critical self- awareness, Culturally responsive curricula and teacher preparation, Culturally responsive and inclusive school environments, and Engaging students and parents in community contexts. These strands or categories, however, turn out not to be not especially discrete. Specific representations of approximately the same general feature appear in at least several—and sometimes all—strands. The features are also framed at widely varying levels of generality (from "uses equity audits" to "is a servant leader ... "). Eight features were assigned to each strand.

In response to some of these characteristics, an alternative conception of the 32 practices is introduced here to summarize the results of this study. This alternative, based simply on a content analysis of the 32 practices, consists of just five sets of practices, each framed at about the same level of generality. CLRS leaders, according to this conception:

- Create and communicate a vision for equity in the school (this practice includes, for example, "promoting a vision for inclusive instruction" and "modeling CRSL for staff ...");

- Collect and use data to identify source of inequity and monitor improvements in equity (for example, for measuring CRSL, using "collaborative walkthroughs", using "equity audits", listening to "student voices", and "using the community as an informative space");

- Adopt a critical perspective on conditions potentially accounting for inequity and act on the results of that perspective (for example, "challenging whiteness and hegemonic epistemologies", committing to "continuous learning of cultural knowledge", "challenging exclusionary policies, teachers and behaviors", "serving as advocate and social activist", implement a "more culturally responsive curriculum");

- Build and sustain productive relationships with all of the school's stakeholders ("build relationships and reduce student anxieties", "develop meaningful positive relationships with the community", "connecting directly with students"); 
- Develop the capacities needed by all of the school's stakeholders to improve equitable conditions and outcomes for students (for example, "create culturally responsive PD opportunities for staff", "develop teacher capacities for culturally responsive pedagogy").

Khalifa et al. [96]. The purpose of this review, as the authors explain, is to "synthesize the literature on how an Indigenous, Decolonizing School Leadership (IDSL) framework, from Western and non-Western spaces seek to decolonize school leadership and build on Indigenous students' ancestral assets and of self-knowledge and self-reflection" [96] (p. 572). People defined as Indigenous are "non-white, non-Western peoples whose ways of being in the world are informed by Indigenous Knowledge" [96] (p. 577). The authors note Hallinger and Leithwood's [97] claim "that Western frameworks have ignored alternative epistemologies in the study and practice of educational leadership. Furthermore, ... because culture shapes a society's shared values, it also determines the educational goals that will dominate the educational system" [96] (p. 587).

For purposes of this review, IDSL consists of five broad strands or domains of practice including awarding priority to the empowerment of community, especially through self-determination, the central influence of community voices and values, service to the community based in altruism and spirituality, and inclusive communication practices aimed at encouraging collectivism. Evidence from the review populates each of these strands with from 3 to 12 de-colonized leadership practices, in all, a total of 29.

Arguments throughout the review aim to demonstrate significant distinctions between Indigenous and non-Indigenous approaches to leadership. That there are significant differences is not contestable. However, these distinctions are exaggerated by the authors' representation of non-Indigenous leadership (e.g., authoritarian, individual, institutional). This representation has largely been discredited and replaced by contemporary conceptions of educational leadership that have significantly more similarities with the authors' description of Indigenous leadership. Of the 29 practices identified by this review, at least a third can be found in the guiding framework. Putting aside the five-strand organization of the remaining practices, a content analysis conducted as part of the current review identified three broad Indigenous leadership practices:

- Acknowledges and is committed to the integrity of Indigenous ways of knowing and knowledge, and resists dominant narratives based on colonizing assumptions;

- Develops curricula and implements forms of pedagogy with staff that are aligned with Indigenous knowledge systems (e.g., by promoting the co-construction of knowledge with students, teachers, and the local community, encouraging learning through storytelling and by embracing students' spirituality);

- Builds and sustains productive relationships with the students' families and the wider local community (e.g., by playing an important role in the local community and the tasks valued by that community, helping build consensus in the community by drawing on its shared culture and history, valuing interpersonal harmony, relationships and community over self and by engaging with students and families in culturally appropriate ways).

Grissom et al. [98]. Using evidence reported since 2000, the purposes of this review were to estimate (1) the size of principal's leadership effects as well as (2) "the links between specific principal characteristics, skills, and behaviors associated with more positive student and school outcomes" [98] (p. 28). Results related to the second of these purposes are especially germane to the current review, especially those results concerned with equitable school leadership, a special interest of Grissom and his colleagues, as with the current review.

This second purpose was accomplished through a synthesis of more than 200 studies. A large proportion of those studies published up to 2012 formed part of the research base on which the guiding framework was built. Therefore, it is not surprising that most of the practices identified by Grissom and his colleagues also appear in the guiding framework. As in the current review, however, the special concern for equity in the Grissom et al. 
review also produced useful adaptations of those core practices when leaders focused on improving equity in their schools; many of those adaptations were the same or very similar to those in Grissom and Loeb [92]. For example, Grissom et al. [98] added to the practice Staffing the Instructional Program, the importance of teachers' race and ethnicity; teachers were significantly less likely to turnover when they and their principals were the same race or ethnicity and teachers' job satisfaction was higher when their principal shared the same race or ethnicity.

As a second example, and part of the guiding framework's domain Building Relationships and Developing People, the Grissom et al. review pointed to successful leadership practices such as Providing professional development, Recognizing the features of high-quality professional development, Caring communication, Building trust, Creating and maintain safe and nurturing environments for everyone in the school, and Communicating effectively using such strategies as open-door policies.

In sum, a large proportion of the core successful leadership practices identified by Grissom and his colleagues were also part of the guiding framework and there is considerable agreement between the results of the current review and Grissom et al. about how those practices can be adapted in the interests of greater equity for students.

Grissom et al. offers a unique conception of how their results are best synthesized. This conception consists of three sets of skills that interact with one another and help leaders successfully enact four domains of behavior or practices. The three sets of skills are labelled:

- People (human development and relationship skills, for example, caring, communication, trust); this category of "skills" overlaps significantly with what the guiding framework describes as "social" PLRs, a category including perceiving one's own and others' emotions, managing the emotions of oneself and others, acting in emotionally appropriate ways. Trust building is included in the guiding framework as a practice.

- Instruction (skills to support teacher classroom instruction such as productive forms of teacher coaching and feedback): this category of skills overlaps with some of the knowledge considered essential for leaders as part of the guiding framework's cognitive PLRs. Other features of what Grissom et al. include as part of this skill set are included among the guiding framework's domain of practices Building Relationships and Developing People, for example, Stimulating growth in the professional capacities of staff.

- Organization (management skills that transcend schools such as strategic thinking and resource management). Some of these "skills" are included in the guiding framework as PLRs, for example, Systems thinking (part of strategic thinking) and others are considered to be practices, for example, Allocating resources in support of the school's vision and goals.

From the perspective of the guiding framework, the skills identified in the Grissom et al. review are either overt practices and behaviors or personal leadership resources.

There are four interrelated domains of especially powerful behaviors or practices included in the Grissom et al. review:

- Engaging in instructionally focused interactions with teachers: this domain includes productive forms of teacher observation and evaluation, the provision of feedback and coaching, and the establishment of a data-driven instructional program. The guiding framework only touches lightly on these specific practices, and revisions to the framework should be more explicit about their inclusion.

- Building a productive climate: practices associated by Grissom et al. as part of a productive climate include, for example, collaboration, engagement with data, a culture of continuous improvement, and "academic optimism". In such a climate, leaders also mentor and empower teachers. While the guiding framework quite explicitly includes the importance of collaboration, along with the three components of academic optimism (as important mediators for principals to influence), it does not mention a culture of continuous improvement. 
- Facilitating collaboration and professional learning communities: most of the practices included in this domain also appear in one or more of the other domains. However, unique to this domain is fostering the use of professional learning communities, something the guiding framework subsumes in the practice Structuring the organization to facilitate collaboration.

- Managing personnel and resources strategically: the Grissom et al. review draws largely on the results reported by Grissom and colleagues summarized earlier in this review and are not repeated here.

In sum, perhaps the main contribution of the Grissom et al. review is not so much the identification of knowledge about successful school leadership not yet published when the guiding framework was developed, but confirmation of the knowledge on which the guiding framework is based with more robust data.

\subsection{Section Four Results}

Individual Studies of Equitable Leadership without Evidence of Outcomes

This section summarizes the results of 19 individual studies (see Appendix B) offering detailed accounts of the practices and dispositions of school leaders who have been identified by themselves or others as committed to improving equitable conditions and outcomes for their students. These studies do not provide explicit evidence about the impact of these leaders on students, but most do illustrate forms of leadership consistent with one or more theories about social justice, equity, inclusion, and the like. An overview of results from these studies is provided in the form of a brief "profile" of equitable school leadership, a limitation aimed at keeping the length of the review relatively manageable. Most of the features described in this profile were also identified in the studies included in earlier sections of the review.

According to these studies, leaders working for equity, social justice, and inclusion:

- Have strong visions for equity guiding the major focus of their work and deep commitments to that work, in some cases, lifelong commitments (e.g., [99], and most other studies);

- Develop strong, productive relationships with families and the wider community (e.g., [100]);

- Have deep knowledge—or work to acquire such knowledge—about (a) effective and equitable educational experiences for the full range of diverse students served by the school (e.g., [101]), (b) in the case of schools serving ELL students, productive approaches to language learning (e.g., [102]), and (c) in the case of schools serving students with disabilities, approaches to inclusion most likely to result in least restrictive environments for students and which converge with the interests of majority families and students;

- Develop collaborative, inclusive school cultures, policies and practices including the distribution of leadership to others (e.g., [103]) and a climate of care, empathy, and respect for students and their families (e.g., [79,104]);

- Model such care, respect, and empathy in their own behavior including listening to the ideas of others (e.g., [105]);

- Identify sources of inequity and oppression in their schools, districts, and communities and find ways to disrupt and reject bias and oppression in its many forms (e.g., [105]);

- Face significant numbers of other, often quite complex, challenges in pursuit of their equity visions and are exceptionally persistent in their efforts to address those challenges (e.g., [106]);

- Exercise high levels of political acumen in those efforts [107,108], adopting a strategic approach that takes into account the interests of others with power (e.g., [109]);

- In schools serving significant numbers of minoritized students, staff their schools with teachers who reflect, for example, the race, culture, and ethnicity of those students; 
- Monitor progress of their efforts to improve equity in their schools using multiple sources of data including the views of students (e.g., [104]) and promising tools such as equity audits (e.g., [79]);

- With staff, implement culturally responsive and instructionally powerful forms of pedagogy [62,99];

- Ensure the use of a curriculum that speaks to the unique cultures, backgrounds, and needs of those diverse students served by the school.

\subsection{Section Five Results}

3.8.1. Summary of Dispositions Enabling More Equitable School Leadership

By far the dominant focus of the studies linking leadership to student outcomes (results section one and two) was about equitable leadership practices. When dispositions were identified, they typically reflected those already part of the guiding framework. Studies included in results sections three and four, however, identified a significant number of dispositions specific to equitable leadership and not already included in the framework. These dispositions, 18 in total, are briefly summarized in this section using three of the four categories of dispositions found in the framework. Leadership dispositions are an understudied feature of successful leadership and only limited analysis of results is provided in this paper.

\subsubsection{Cognitive Dispositions Enabling Equitable Leadership}

1. Self-knowledge through regular engagement in critical self-reflection, [26,33,110,111];

2. A personal anti-racist identity [95];

3. Deep knowledge about the diverse ethnicities, languages, cultures, religions, and living circumstances of students' families $[33,46,95]$. This knowledge also includes, for example, an understanding of understanding of Indigenous ways of knowing and knowledge [96];

4. Deep knowledge about effective and equitable educational experiences for the full range of diverse students served by the school (e.g., [101]). In the case of schools serving ELL students, for example, this knowledge is about productive approaches to language learning e.g., [102] and in the case of schools serving students with disabilities, this is knowledge about the approaches to inclusion most likely to result in the least restrictive environments for students and that converge with the interests of majority families and students;

5. A critical perspective on conditions in the school and community potentially accounting for inequity [26,111];

6. A critical perspective on policies and practices intended to improve equity in order to ensure that these policies and practices do not perpetuate racial inequities $[26,95,111]$.

\subsubsection{Psychological Dispositions Enabling Equitable Leadership}

1. Passion and commitment about achieving greater equity for students; this includes a commitment to the integrity of Indigenous ways of knowing and knowledge [96];

2. Resistance to dominant narratives based on colonizing assumptions [96];

3. A robust sense of self efficacy about improving social justice in one's school including a personal sense of "being right", but humble about one's accomplishments [33];

4. The courage required for disrupting and resisting sources of bias and racism among staff and other stakeholders as well as engaging in difficult conversations with staff and other stakeholders about bias, deficit perspectives, and more. Such courage is also exercised in the face of community and accountability pressures $[33,111]$.

3.8.4. Dispositions Related to Values and Ethics which Enable Equitable Leadership

1. A strong vision for equity guiding the major focus of one's work and a deep commitment to that work (e.g., $[33,99,111]$ and most other studies);

2. A tenacious, life-long commitment to social justice [33];

3. Beliefs about every child deserving a rewarding education that delivers long-term benefits [111]; 
4. A strong moral purpose including a heightened sense of awareness related to the marginalization of students with disabilities, and habits of mind that help identify and challenge sources of oppression [111].

\section{Conclusions}

This is a narrative review of research and theory aimed at identifying school leadership practices and dispositions that help to improve equitable school conditions and outcomes for diverse and traditionally underserved students. Evidence for the review included 27 quantitative and mixed methods studies and 10 large-scale quantitative studies reporting leadership effects on student outcomes. An additional seven reviews of theory were examined, along with 19 qualitative studies describing productive practices and dispositions as perceived by self-identified social justice leaders.

Analysis of this evidence was guided by a well-developed framework of successful leadership practices and dispositions (e.g., [13]) Providing evidence useful in refining that framework with a more explicit focus on equity was a central motivation for carrying out the review. Results indicate that almost all of the leadership practices in the framework can be enacted in ways that contribute to equitable conditions and/or outcomes for students. School leaders, these results suggest, have the potential to positively influence improvements in the equitable treatment of students in their schools in almost everything that they do, not just through some practices or dispositions uniquely designed for improving equity.

Key Results

While a wide range of practices potentially influence equity, some of these practices make especially significant contributions. This was evident from the large number of studies pointing to those practices and the importance authors attached to them. The most powerful set of practices that equity-oriented school leaders enact is to create authentic partnerships among schools, families, and communities aimed at ensuring student success. These partnerships have the potential to enrich conditions in the home with significant contributions to student success at school (e.g., increase parent expectations for student success); they also have the potential to engage otherwise reluctant parents to participate with the school in decisions about how the school might better contribute to their children's success at school. This might be viewed as an indirect strategy for increasing equity in a school; as Rivera-McCabe [111] notes, rather than focusing on the superficial needs of the child, the principals in this study were emphatic about addressing the needs of the family in the interest of supporting the child [111] (p. 757).

A second especially powerful set of practices used by equity-oriented leaders is ensuring that the curriculum guiding instruction in their schools acknowledges and makes use of the ethnic, cultural, and linguistic assets that diverse students and their families bring to the school (sometimes referred to as "funds of knowledge" and "funds of identity". (For a recent review of research about both of these concepts, see Hogg and Volman [112]. Limited evidence of the contributions of both FoK and FoI is reported in Volman [113] and Rios-Aguilar, C. [114]). While authorities outside of schools establish the formal curriculum to be followed by schools in most educational jurisdictions, leaders improve equity in their schools by supplementing or refining their schools' curriculum in order to reflect and make use of these family, community, and student assets.

Third, school leaders significantly improve equity in their schools when they assist teachers with the implementation of ambitious forms of instruction for traditionally underserved students. These forms of instruction actively engage students, are culturally responsive, carefully scaffolded, constructivist, often aimed at developing deep understanding, and that help ensure that the curriculum is clearly relevant to all students [77]. This approach to instruction is much more common for non-minoritized middle class students than it is for economically challenged and minoritized students, but it makes especially important contributions to the learning of those economically challenged and minoritized students [115]. 
School leaders who significantly improve equity in their schools are considerably more than the sum of their practices. Equity-oriented leaders have a strong vision of equity for their school and pursue that vision by adopting a critical perspective on school practices, policies, and structures. These leaders courageously challenge bias and oppression among all of the schools' stakeholders and are passionate about improving the life chances of all students. Equity-oriented leaders develop deep knowledge about the ethnicities, languages, cultures, religions, and living circumstances of students' families and use that knowledge to align the school's priorities with the best interests of their students' families and the wider community. However, these leaders often face complex and unpredictable challenges in their efforts to improve equity in their schools, challenges no fixed set of "successful" leadership practices is likely to suffice. In such circumstances, the dispositions identified in this review seem likely to be a primary source of guidance for their work.

Implications for practice. Results of this review offer advice to school leaders about some of the most promising practices they might use in their efforts to improve equity in their schools. The detailed outline of practices in the first section of results serves as a resource for those leaders reflecting on the work they are doing in their own schools and what more they might do. Those responsible for coaching novice leaders might also use the results of the review as a guide to the feedback they provide to those they are coaching.

The dispositions associated with equitable leaders described in the review should be included among the criteria used by district leaders engaged in leadership recruitment and selection. Because dispositions (e.g., strong moral purpose) may be the starting points for leaders' decisions about how to act, privileging dispositions among hiring criteria seems warranted. Furthermore, while most of the dispositions identified in this review are potentially malleable over time, selecting those dispositions is a quicker and more certain way of improving equity-oriented leadership in a district's schools.

Implications for future research. One of the most noteworthy features of the research included in this review was the almost exclusive use of qualitative methods with small samples.

The search strategy failed to identify a single large-scale quantitative study testing the effects of some explicit model of equitable leadership on either a promising set of equitable school conditions and/or a desirable set of student outcomes. Section 3 includes large-scale studies linking leadership practices to student outcome, however, these reviews did not measure leadership explicitly conceptualized as equitable. Surprised by this failure, twelve senior researchers in the field of educational leadership were contacted, several of whom were also editors of relevant journals, requesting help in locating studies of this sort. None of these contacts were able to identify any such studies; while this does not mean there are none, it does mean that they are at least very rare. As a result, the many decades of research about equitable leadership still do not meet the minimum standards of a robust body of knowledge, that is, knowledge emerging from significant numbers of studies using a variety of research designs each with its own unique strengths and weaknesses.

This lack of variation in research design is an enormous shortcoming that needs to be rectified by future research with a much greater emphasis on large-scale quantitative methods. The broader field of educational leadership and management now includes a large and increasingly sophisticated corpus of quantitative research, using increasingly sophisticated methods, but almost exclusively preoccupied with integrated, instructional, learning-centered, and transformational conceptions of such leadership. It is long past time for the application of similar designs and methods to assess the relative value of the many practices and dispositions currently associated in the literature with equitable leadership.

Funding: This review was self funded.

Institutional Review Board Statement: This is a review of previously published studies.

Informed Consent Statement: This is a review of previously published studies.

Data Availability Statement: All data source can be found in the cited studies.

Conflicts of Interest: The author declares no conflict of interest. 


\section{Appendix A}

Table A1. Studies of equity-oriented school leadership with evidence of impact.

\begin{tabular}{|c|c|c|c|c|}
\hline Authors & Purposes & $\begin{array}{c}\text { Guiding } \\
\text { Concepts/Theories }^{1}\end{array}$ & Methods & General Results \\
\hline $\begin{array}{l}\text { Angelides et al., } 2010 \\
\text { [79] }\end{array}$ & $\begin{array}{l}\text { Determine how school leaders develop } \\
\text { inclusive practices in their schools. }\end{array}$ & Inclusive education. & $\begin{array}{c}\text { Outlier design } \\
\text { Single case study } \\
\text { Participant observation, interviews, } \\
\text { documents. }\end{array}$ & $\begin{array}{l}\text { School leader: } \\
\text { Involved teachers in decision making and distributed leadership; } \\
\text { Encouraged co-teaching; } \\
\text { Fostered a collaborative culture; } \\
\text { Promoted a love, care, acceptance and involvement of children; } \\
\text { Involved parents and the community in the school }\end{array}$ \\
\hline $\begin{array}{c}\text { Bills, Cook \& Giles, } 2015 \\
\text { [48] }\end{array}$ & $\begin{array}{l}\text { Determine how to engage } \\
\text { disenfranchised young people back into } \\
\text { formalized senior secondary schooling. }\end{array}$ & Emancipatory Leadership. & $\begin{array}{l}\text { Critical action research in a new "second } \\
\text { chance" school over a three-year period } \\
\text { Observations, reflections on the work, } \\
\text { interviews. }\end{array}$ & $\begin{array}{l}\text { Key aspects of the leadership provided by the teacher-founders of the } \\
\text { school: strategic social entrepreneurial activism; critical praxis for } \\
\text { socially just school design (SJSD); ongoing efforts to acquire the } \\
\text { funding needed by the school. }\end{array}$ \\
\hline $\begin{array}{l}\text { DeMatthews \& } \\
\text { Mawhinney } \\
2014 \text { [116] }\end{array}$ & $\begin{array}{l}\text { Describe the challenges that two } \\
\text { principals addressed while attempting to } \\
\text { transform their school cultures to } \\
\text { embrace an inclusion model for students } \\
\text { with disabilities. }\end{array}$ & $\begin{array}{l}\text { Social Justice and } \\
\text { Inclusion Leadership. }\end{array}$ & $\begin{array}{c}\text { Two school leaders committed to social } \\
\text { justice for students with disabilities. } \\
\text { Interviews with principals over a year. } \\
\text { Observations of principals, teachers and } \\
\text { other staff. }\end{array}$ & $\begin{array}{l}\text { Two principals enacted social justice leadership by making decisions } \\
\text { that addressed resistance and challenges to inclusion. Highlight the } \\
\text { significant challenges and dilemmas faced by both principals. }\end{array}$ \\
\hline Demie, 2019 [36] & $\begin{array}{l}\text { Identify the factors explaining the } \\
\text { success of schools exceptionally } \\
\text { successful in raising the achievement of } \\
\text { Black Caribbean students. }\end{array}$ & $\begin{array}{l}\text { Leadership and work } \\
\text { force diversity factors. }\end{array}$ & $\begin{array}{l}\text { Outlier design. } \\
\text { Case studies in } 8 \text { primary and } 6 \text { secondary } \\
\text { schools in inner London. } \\
\text { Interviews, observations, focus groups. }\end{array}$ & $\begin{array}{ll}\text { Successful leadership practices: } \\
- & \text { Established a strong vision for the school/set clear directions. } \\
- & \text { Held high expectations. } \\
- & \text { Staffed school with a workforce that reflects its pupils' } \\
\text { characteristics. } \\
- & \text { Provided ample professional development for staff. } \\
- & \text { Build productive teams/distributed leadership. } \\
- & \text { Detailed knowledge and commitment to local community. } \\
- & \text { Habits of mind that help identify and challenge oppression. } \\
- & \text { Respect and celebrate diversity. } \\
- & \text { Use ethnicity to track student progress. } \\
- & \text { Ensure use of a multicultural curriculum. }\end{array}$ \\
\hline $\begin{array}{l}\text { Garza, } \\
\text { Murakami-Ramahlo \& } \\
\text { Merchant, } 2011[117]\end{array}$ & $\begin{array}{l}\text { Describe the successful leadership of one } \\
\text { principal experiencing a transition to a } \\
\text { new school. }\end{array}$ & $\begin{array}{l}\text { Five domains of } \\
\text { successful leadership } \\
\text { practices. }\end{array}$ & $\begin{array}{l}\text { Outlier design. } \\
\text { Students demonstrated continuous } \\
\text { improvement on state tests. }\end{array}$ & $\begin{array}{l}\text { Principal's success was a function of: a strong sense of efficacy, } \\
\text { respectful and positive attitude toward her students and staff, } \\
\text { building strong bonds with parents and community, high expectations } \\
\text { for students' performance. }\end{array}$ \\
\hline
\end{tabular}


Table A1. Cont.

\begin{tabular}{|c|c|c|c|c|}
\hline Authors & Purposes & $\begin{array}{c}\text { Guiding } \\
\text { Concepts/Theories } 1\end{array}$ & Methods & General Results \\
\hline Gurr et al., 2018 [43] & $\begin{array}{l}\text { Describe how culture, context and } \\
\text { leadership interacted to improve school } \\
\text { outcomes. }\end{array}$ & $\begin{array}{l}\text { Elements of the guiding } \\
\text { Framework. }\end{array}$ & $\begin{array}{l}\text { Three schools initially underperforming by } \\
\text { now on an improvement trajectory. Case } \\
\text { studies: interviews, observations, and } \\
\text { documents. }\end{array}$ & $\begin{array}{l}\text { Conclusion returns to the four domains framework and illustrates } \\
\text { how leadership is exercised, depending on context, within those } \\
\text { domains. } \\
\text { Extensive discussion of context framed by Hallinger's taxonomy of } \\
\text { both cultures and context. }\end{array}$ \\
\hline Irvine et al., 2010 [39] & $\begin{array}{l}\text { Understand how rural school leaders } \\
\text { create authentic inclusive schools for } \\
\text { students with exceptional needs }\end{array}$ & $\begin{array}{l}\text { Authentic inclusion. } \\
\text { Inclusive } \\
\text { education/social justice. }\end{array}$ & $\begin{array}{l}\text { Surveys of all principals and } \\
\text { vice-principals in one rural school district: } \\
\text { Interviews with } 4 \text { principals. } \\
\text { Special needs students survey }(n=16) \text { and } \\
\text { interviews }(n=4) \text { of principals in one rural } \\
\text { district. }\end{array}$ & $\begin{array}{l}\text { Key factors for success include: collaboration among key players in } \\
\text { the students' education; opportunities for professional development; } \\
\text { communication and collaboration with parents, staff and community; } \\
\text { access to a range of resources; commitment to meeting the needs of all } \\
\text { students. }\end{array}$ \\
\hline Ishimura, 2013 [46] & $\begin{array}{l}\text { Describe conditions and that enable } \\
\text { principals to share leadership with } \\
\text { teachers and low-income Latino parents } \\
\text { to improve student learning. }\end{array}$ & $\begin{array}{l}\text { Shared leadership. } \\
\text { Principal as organizer. }\end{array}$ & $\begin{array}{l}\text { Case studies of small autonomous schools } \\
\text { initiated by a community-organizing } \\
\text { group. Interviews with principals, } \\
\text { teachers, parents, others; documents, } \\
\text { observations }\end{array}$ & $\begin{array}{c}\text { Principals assumed roles of community organizer enacted this model } \\
\text { of the "principal as organizer" }\end{array}$ \\
\hline Ishimura, 2018 [110] & $\begin{array}{l}\text { Deepen the understanding of how } \\
\text { minoritized families and communities } \\
\text { contribute to equity-focused school } \\
\text { change. }\end{array}$ & $\begin{array}{l}\text { Equitable collaborations } \\
\text { and Institutionalized } \\
\text { scripts. }\end{array}$ & $\begin{array}{l}\text { Outlier design. One qualitative case study } \\
\text { of a high poverty, racially diverse school in } \\
\text { US west. } \\
\text { Interviews with } 10 \text { predominantly African } \\
\text { American parents. }\end{array}$ & $\begin{array}{l}\text { Minoritized families, community leaders and formal leaders } \\
\text { leveraged conventional schooling structures—-such as turnaround } \\
\text { reforms, the International Baccalaureate program and the PTA- to } \\
\text { disrupt the default institutional scripts of schools and drive } \\
\text { equity-focused change for all students, particularly } \\
\text { African-Americans from the neighborhood. }\end{array}$ \\
\hline $\begin{array}{l}\text { Jacobson \& Notman, } \\
2018[58]\end{array}$ & $\begin{array}{l}\text { Determine the practices of ECE leaders } \\
\text { that enhanced parental involvement and } \\
\text { student success communities in New } \\
\text { Zealand (NZ). }\end{array}$ & $\begin{array}{l}\text { Elements of the guiding } \\
\text { Framework. }\end{array}$ & $\begin{array}{l}\text { Three quality early childhood education } \\
\text { (ECE) centers serving diverse, high needs } \\
\text { students. } \\
\text { Interviews with parents. }\end{array}$ & $\begin{array}{l}\text { ECE leadership that supports parental involvement and out-of-school } \\
\text { parenting skills complements in-school efforts, and together they have } \\
\text { the potential to improve children's life chances. } \\
\text { Leaders implanted three core leadership domains. }\end{array}$ \\
\hline Khalifa, 2012 [59] & $\begin{array}{l}\text { Understand the impact that a principal's } \\
\text { community- leadership had on } \\
\text { school-community relations and student } \\
\text { outcomes. }\end{array}$ & $\begin{array}{l}\text { School and community } \\
\text { "overlapping spheres". }\end{array}$ & $\begin{array}{l}1 \text { small alternative secondary school. } \\
80 \% \text { African American students. } \\
\text { Interviews, observations with principal, } \\
\text { teachers, parents, students. }\end{array}$ & $\begin{array}{l}\text { Principals was successful because of: } \\
\text { High visible in the community; fluid and intimate relationship with } \\
\text { community; advocacy of community causes; inclusion of parents and } \\
\text { community members into the school context; creation of structures } \\
\text { and processes that embraced home and school environments }\end{array}$ \\
\hline
\end{tabular}


Table A1. Cont.

\begin{tabular}{|c|c|c|c|c|}
\hline Authors & Purposes & $\begin{array}{c}\text { Guiding } \\
\text { Concepts/Theories }{ }^{1}\end{array}$ & Methods & General Results \\
\hline Klar \& Brewer, 2013 [52] & $\begin{array}{l}\text { Identify how particular leadership } \\
\text { practices and beliefs were adapted to } \\
\text { increase student achievement in this } \\
\text { rural, high-poverty school in the } \\
\text { Southeastern USA. }\end{array}$ & $\begin{array}{l}\text { Elements of the guiding } \\
\text { Framework. }\end{array}$ & $\begin{array}{l}\text { One case study school. } \\
12 \text { interviews, documents, on line survey } \\
\text { administered to all school staff. }\end{array}$ & $\begin{array}{l}\text { Demonstrated how the framework practices led to students at this } \\
\text { school, previously the lowest performing in the district, achieving } \\
\text { significantly higher on state standardized tests, getting along "like a } \\
\text { family," and regularly participating in service learning activities and } \\
\text { charity events. The principal confronted the school's negative } \\
\text { self-image and adapted leadership practices to implement a } \\
\text { school-wide reform that suited its unique context. }\end{array}$ \\
\hline $\begin{array}{c}\text { Klar, Brewer \& } \\
\text { Whitehouse, } 2013 \text { [70] }\end{array}$ & $\begin{array}{l}\text { Identify leadership practices effective in } \\
\text { improving the achievement of students } \\
\text { in high needs schools. }\end{array}$ & $\begin{array}{l}\text { Elements of the guiding } \\
\text { Framework. }\end{array}$ & $\begin{array}{l}\text { Three high poverty, racially diverse } \\
\text { students. } \\
\text { Mixed methods: } \\
\text { 3-day site visits including observations, } \\
\text { interviews, and document analysis. }\end{array}$ & $\begin{array}{l}\text { Results summarized using four core domains of practice and } \\
\text { demonstrating how the practices are useful in responding to high } \\
\text { needs schools and adapting them to the particular context of the } \\
\text { schools. }\end{array}$ \\
\hline Medina et al., 2014 [118] & $\begin{array}{l}\text { Describe successful leadership in } \\
\text { high-need schools. }\end{array}$ & None. & $\begin{array}{l}\text { Two Latina primary school principals and } \\
\text { their high need schools. } \\
\text { Data were communicated through dialogic } \\
\text { narratives with minimal intervention. }\end{array}$ & $\begin{array}{l}\text { The two principals defined their leadership as a moral craft, one that } \\
\text { prepares adults on campus to support families and students in urban } \\
\text { high-need areas. Considerations of socio-economic issues, and } \\
\text { unaddressed academic, emotional, and physical issues, were regarded } \\
\text { as needs to be met before focusing on students' academic success. } \\
\text { Leaders emphasized their role in preparing school staffs to support } \\
\text { parents, families, and students }\end{array}$ \\
\hline $\begin{array}{l}\text { Nabhani, Busher, } \\
\text { Bahous, } 2012 \text { [48] }\end{array}$ & $\begin{array}{l}\text { Determine why students in four private } \\
\text { primary schools outperformed students } \\
\text { in peer schools. }\end{array}$ & $\begin{array}{l}\text { Models of school } \\
\text { improvement for schools } \\
\text { in challenging } \\
\text { circumstances. Elements } \\
\text { of the guiding Framework }\end{array}$ & $\begin{array}{l}\text { Case studies of } 4 \text { private primary schools } \\
\text { in Beirut serving economically challenged } \\
\text { students. } \\
\text { Semi structured interviews (principals, } \\
\text { teachers, students), documents, } \\
\text { observations. }\end{array}$ & $\begin{array}{l}\text { Explanations for the schools' success was explained by the extent to } \\
\text { which leaders' approach to improvement reflected many of the } \\
\text { practices in guiding Framework" collaborative cultures; engaging } \\
\text { forms of instruction; ongoing professional development of teachers; } \\
\text { uses of assessment for learning; safe and orderly environments, strong } \\
\text { relationships with parents; adherence to a shared set of values. }\end{array}$ \\
\hline
\end{tabular}


Table A1. Cont.

\begin{tabular}{|c|c|c|c|c|}
\hline Authors & Purposes & $\begin{array}{c}\text { Guiding } \\
\text { Concepts/Theories } 1\end{array}$ & Methods & General Results \\
\hline $\begin{array}{c}\text { Notman \& Henry, } 2011 \\
\text { [38] }\end{array}$ & $\begin{array}{l}\text { Determine the extent to which successful } \\
\text { principalship in New Zealand is } \\
\text { contingent upon a successful } \\
\text { relationship between a school and its } \\
\text { community? }\end{array}$ & $\begin{array}{l}\text { Instructional leadership } \\
\text { skills and personal } \\
\text { characteristics. } \\
\text { Context effects. }\end{array}$ & $\begin{array}{l}\text { Case studies of } 6 \text { successful primary and } \\
\text { secondary principals. } \\
\text { Interviews, surveys of all stakeholder } \\
\text { groups, observations of principals at work. }\end{array}$ & $\begin{array}{l}\text { Four thematic headings: } \\
\text { Personal characteristics through which principals demonstrate their } \\
\text { inter- personal skills and sense of personal identity; leadership skills } \\
\text { that principals employ to connect with their teachers on a professional } \\
\text { and a personal level; } \\
\text { leadership strategies that are strongly linked to student, teacher, and } \\
\text { school community needs; leadership sustainability that contributes to } \\
\text { improved student achievement. } \\
\text { Major factors include: principals' capacity for reflection on self and on } \\
\text { school; responsiveness to contingent factors impacting on each school } \\
\text { environment; a relational connectedness to all sectors of the school } \\
\text { community, and resilience in the face of often complex and competing } \\
\text { demands. }\end{array}$ \\
\hline
\end{tabular}

Okilwa \& Barnett, 2017 To describe how four successive school [47] cess of students in a high school.

\section{Change management and} Organizational turnaround theor

Single case study Evidence from a longitudinal data based on: state-level academic and demographic data; two earlier studies of the school; and recent interviews with teachers, the principal, and parent leaders.

Role of contexts in

Illustrate the importance of adapting Okilwa \& Barnett, 2018 school leadership practices to the unique [55]

features of the community, district and school contexts.

shaping what effective leaders do.

\section{Single case study}

Semi-structured interviews with four principals who served the school from the

early 1990s, the time when school Stress the school and local community context as well as the district. turnaround started, until the present. Interviews with three veteran teachers and two parent leaders.

Leadership practices responsible for sustained academic performance included high expectations, distributed leadership, collective responsibility for student performance, and data-based decision making.

Based on their contextual analysis of the community and school, these principals took proactive measures to alter school programs and practices in order to improve student achievement, teacher

performance, community engagement, and relationships with district

administration.
These principals were adroit at understanding and responding to their contexts manifesting most of the capacities and dispositions associated with expert problem solving.

Instructional and entrepreneurial leadership are two vital and complementary constituents of successful leadership. Instructional leadership included: vision building and

Describe how school principals combine Pashiardis \& Savvades, instructional and entrepreneurial aspects 2011 [37] of leadership in their effort to build capacity for student learning.
Case studies in four rural primary schools in Cyprus.

Semi-structured interviews with principals, teachers, parents and students. Documents. communication; high expectations for all; professional development for principals and teachers.

Entrepreneurial leadership included: parent engagement; involve the wider community in the school; project the school into the community; acquire resources for the schools. 
Table A1. Cont.

\begin{tabular}{|c|c|c|c|c|}
\hline Authors & Purposes & $\begin{array}{c}\text { Guiding } \\
\text { Concepts/Theories } 1\end{array}$ & Methods & General Results \\
\hline $\begin{array}{l}\text { Pashiardis et al., } 2010 \\
\text { [51] }\end{array}$ & $\begin{array}{l}\text { Identify the personal qualities and } \\
\text { professional competencies generic to } \\
\text { effective school leaders }\end{array}$ & $\begin{array}{l}\text { Learning-centered, values } \\
\text { driven leadership. }\end{array}$ & $\begin{array}{l}\text { Case studies in five rural primary schools } \\
\text { in Cyprus. } \\
\text { Semi-structured interviews with principals, } \\
\text { teachers, parents and students. } \\
\text { Documents. }\end{array}$ & $\begin{array}{l}\text { Successful leaders were: people-centered leadership; clearly } \\
\text { communicated values and visions; had a strong emphasis on the } \\
\text { promotion of learning; the use of networked leadership; creative } \\
\text { management of competing values. }\end{array}$ \\
\hline Preston et al., 2017 [57] & $\begin{array}{l}\text { Describe the perceptions and practices of } \\
\text { principals who promote positive school } \\
\text { experiences for Aboriginal students. }\end{array}$ & $\begin{array}{l}\text { Indigenous Leadership } \\
\text { Style. }\end{array}$ & $\begin{array}{l}\text { Four case studies. } \\
\text { Interviews with principals. }\end{array}$ & $\begin{array}{l}\text { Effective leaders for Aboriginal students: believe that Aboriginal } \\
\text { students can learn and they hold high expectations for such learning; } \\
\text { foster a sense of belonging (space and place) as well as feelings of } \\
\text { physical safety among Aboriginal students; develop strong, trusting } \\
\text { relationship with students, parents and Aboriginal communities; } \\
\text { provide culturally relevant school experiences including relevant } \\
\text { indigenized teaching and programs and tutorage. }\end{array}$ \\
\hline $\begin{array}{l}\text { Silva, White \& Yoshida, } \\
2011[35]\end{array}$ & $\begin{array}{l}\text { Determine the direct effects of a school } \\
\text { principal on student reading } \\
\text { achievement. }\end{array}$ & $\begin{array}{l}\text { Three components of } \\
\text { instructional leadership: } \\
\text { communicate a mission } \\
\text { directly to students; } \\
\text { involve students in } \\
\text { monitoring their own } \\
\text { progress; communicate } \\
\text { high expectations directly } \\
\text { to individual students. }\end{array}$ & $\begin{array}{l}\text { Experimental design } \\
\text { Quasi-experiment } \\
20 \text { students in the treatment group, } 21 \text { in } \\
\text { the control group. }\end{array}$ & $\begin{array}{c}\text { One-on-one discussions between a principal and a nonproficient } \\
\text { student that focused on the student's reading score and a goal for his } \\
\text { or her future reading score had a direct and significant effect on the } \\
\text { student's subsequent reading achievement gains on a state } \\
\text { reading test. }\end{array}$ \\
\hline $\begin{array}{l}\text { Szeto, Cheng \& Sin, } \\
2019 \text { [120] }\end{array}$ & $\begin{array}{l}\text { What challenges do principals face in } \\
\text { diverse student populations? What } \\
\text { practices do principals adopt to support } \\
\text { the learning development of these } \\
\text { students? What support do the } \\
\text { principals need most to enact this } \\
\text { leadership? }\end{array}$ & $\begin{array}{l}\text { Principal leadership for } \\
\text { inclusion in the context of } \\
\text { difference and difficulty. } \\
\text { Economic, cultural and } \\
\text { associational challenges. }\end{array}$ & $\begin{array}{l}\text { Two Hong Kong schools and principals. } \\
\text { Interviews, documents and artefacts. }\end{array}$ & $\begin{array}{l}\text { Principals' inclusive leadership practices included: cultivation of } \\
\text { equality; equity and inclusion for student development in diversity; } \\
\text { reliance on principals' value systems regarding difference and } \\
\text { difficulty in diversity; innovative leadership practices beyond the } \\
\text { boundary of traditional and hierarchical school administration. }\end{array}$ \\
\hline
\end{tabular}


Table A1. Cont.

\begin{tabular}{|c|c|c|c|c|}
\hline Authors & Purposes & $\begin{array}{c}\text { Guiding } \\
\text { Concepts/Theories }{ }^{1}\end{array}$ & Methods & General Results \\
\hline $\begin{array}{l}\text { Theoraris \& O'Toole, } \\
2011[42]\end{array}$ & $\begin{array}{l}\text { Describe the leadership necessary to } \\
\text { create socially just schools for English } \\
\text { language learners (ELLs). }\end{array}$ & $\begin{array}{l}\text { Leadership, Social Justice } \\
\text { and English Language } \\
\text { Learners. }\end{array}$ & $\begin{array}{l}2 \text { urban elementary schools and their } \\
\text { principals. }\end{array}$ & $\begin{array}{l}\text { Successful leaders: possessed an asset-based orientation toward } \\
\text { language; had beliefs that inclusive services benefited ELL students } \\
\text { and their peers; had knowledge of ELL research, professional } \\
\text { development, and the danger of pullout instruction. } \\
\text { These leaders possessed the skills to facilitate a collaborative planning } \\
\text { and implementation process; to create new ways of delivering } \\
\text { services; to provide necessary and focused professional development; } \\
\text { to maintain communication with all stakeholders. } \\
\text { These principals; believed they were responsible for ensuring that } \\
\text { ELLs received an equitable, excellent, and inclusive education; ability } \\
\text { to imagine services and plans they had not seen in practice before; a } \\
\text { sense of agency about improvement. }\end{array}$ \\
\hline Wilson, 2016 [56] & $\begin{array}{l}\text { Determine how to address and } \\
\text { ameliorating conditions of oppression, } \\
\text { poverty, or deprivation'. }\end{array}$ & $\begin{array}{c}\text { Theories of } \\
\text { Transformative } \\
\text { Leadership and Critical } \\
\text { Care. }\end{array}$ & $\begin{array}{l}\text { Single case study } \\
\text { Interviews, documents, observations. }\end{array}$ & $\begin{array}{l}\text { Transformative leadership involved: enacting critical care that } \\
\text { encompassed empathy, compassion, advocacy, systemic critique, } \\
\text { perseverance and risk- taking for the sake of advancing student } \\
\text { learning and social justice. } \\
\text { Redressing inequity sometimes involves pushing ideological, } \\
\text { curricular, organizational and/or political boundaries that district } \\
\text { officials may prefer to keep intact. }\end{array}$ \\
\hline
\end{tabular}

${ }^{1}$ These are the concepts/theories explicitly identified by the study authors.

\section{Appendix B}

Table A2. Studies of equity-oriented school leadership without evidence of impact.

\begin{tabular}{|c|c|c|c|c|}
\hline Authors & Purposes & Guiding Concepts/Theories & Methods & General Results \\
\hline $\begin{array}{l}\text { Angelides, Antoniou \& } \\
\text { Charalambous, } 2010 \text { [79] }\end{array}$ & $\begin{array}{l}\text { Determine leadership practices that cultivate } \\
\text { inclusive education? }\end{array}$ & Inclusive education. & $\begin{array}{l}\text { Single case study: observations; } \\
\text { interviews; documents }\end{array}$ & $\begin{array}{l}\text { Most important leadership practices: involve } \\
\text { teachers and distribute power (most important); } \\
\text { encourage co-teaching; nurture development of a } \\
\text { collaborative culture; encourage and model an } \\
\text { ethic of care and acceptance of all children; involve } \\
\text { parents and the community. }\end{array}$ \\
\hline Chang, 2019 [121] & $\begin{array}{c}\text { Describe conceptions of equity within technology } \\
\text { leadership studies and offer alternative } \\
\text { possibilities for equitable technology leadership } \\
\text { practice. }\end{array}$ & $\begin{array}{l}\text { Ishimaru and Galloway's (2014) [25] } \\
\text { 'Three drivers of equitable } \\
\text { leadership practice: Framing } \\
\text { disparities and action; Construction } \\
\text { and enactment of Leadership; } \\
\text { Inquiry culture.' }\end{array}$ & $\begin{array}{c}\text { Single case study } 9 \text { months of participant } \\
\text { observation. } \\
12 \text { interviews. }\end{array}$ & $\begin{array}{l}\text { Participatory vision-setting processes allowed for a } \\
\text { more contested view of 'technology' to emerge. } \\
\text { Digital tools fostered youth civic engagement, but } \\
\text { also represented looming threats of displacement } \\
\text { and gentrification. }\end{array}$ \\
\hline
\end{tabular}


Table A2. Cont.

\section{Authors}

Purposes

Describe how school leaders navigate Arizona's restrictive language policies to support dual language learners academic achievement and integration.

\section{Guiding Concepts/Theories}

Culturally and Linguistically

Diverse Leadership (CLD) dimensions.
Methods

3 case studies of elementary schools and their principals in one Arizona district with high proportions of Latino students. Semi-structured interviews with principals
Identify how one Spanish female principal built a Cruz-González, Muñoz \& professional identity oriented towards leadership Segovia, $2020[103$ justice.
Leadership and gender identity.

Development of a professional biogram based on the leader's reflections on key events in her life.

\section{General Results}

Illustrates how each of the three CLD dimensions was used: Ensuring academic achievement;

Cultivating language proficiency; Facilitating sociocultural integration.

\section{Over her career, this principal:}

chose a leadership identity based on empathy and community; consolidated her values of democracy, social justice and professional commitment: distributed leadership by opening the school door to the outside world

promoted the professional commitment of teachers and their teamwork skills, developed capacities to listen.

Case study of one principal in one high poverty urban school serving a high
Describe the leadership of one elementary school principals who was successful in creating a more inclusive school.
Describe how leaders in an Islamic school in the United States engaged in culturally relevant community to develop students' critical social consciousness. leadership (CRL) within a diverse school
Fass, Smith \& Darmody, $2018[62$
Describe how principals help to establish inclusive and supportive school environments.

Questionnaires, semi-structured bullying policies; highlighting student diversity; population of African American students. Interviews; Observations focused on the principal engaged in leadership actions.
Culturally Relevant Leadership (CLR).
Data collected in one school over four

years from teachers. Students, parents, community leaders:
Culturally responsive leadership. interviews; focus group interviews; classroom observations

The principal turns out to have been partially successful at best.

CRL was grounded in inter- and intra-faith dialogue, cultural syncretism, and a unique focus

on the development of an American Muslim identity.Critical to CRL were: Liberatory consciousness; Pluralistic insight, and Reflexive practice.

Mixed-methods study in 11 schools, which were part of state-funded multi-denominational community national schools in Ireland. interviews with 11 principals and 22 teachers.

Student focus groups.

15 Indigenous female leaders from

"To authenticate and legitimate Indigenous women's voices through theorizing their leadership realities and by situating such knowledge in the cultural spaces that they occupy" (p. 93)
Explicitly chose not to frame the study theoretically.
Canada, Australia and New Zealand. Face to face interviews.
Principals helped to create more equitable schools by: aligning admission policies; establishing anti demonstrating respect for diverse students; helping to build social cohesion within the school; implementing culturally responsive teaching practices.

Documents the "extent to which ideologies of oppression continue to impact the everyday lives and work of Indigenous women" (p. 93). 
Table A2. Cont.

Authors

Purposes

A comparison of two principals leading

high-needs schools, identifying what is

distinctive about leading these schools.

Social justice.
Describe school actors' perceptions of the

Hajisoteriou et al., 2018 [104] successful components of school improvement culturally diverse schools.
Inclusive school culture. Social justice.
Stimulate thinking about diversity and

leadership and to support reflection on related issues.
Identify and diversity
[122]
2 schools (England, South Africa. Interviews with 15 leaders and teachers

susta

The way in which the respondents conceptualized

way each person's identity is conceived in two very different nations seem to sustain the invisibility of whiteness and the failure to address the unwarranted privilege" (p. 17).

Variation in school contexts make some practices more likely than others.

When a school in facing a significant challenge strong, top-down leadership may be required to begin turning the school around. As the pressure
subsides shifting to a more distributed model seems suitable. parents and other community groups often important, including building the skills parents

needed to better help their students.

Modeling the vision also often important.

1 elementary school in Texas serving low income, non-native speaking and traditionally excluded students. Document analysis. Participant
Results describes what might be a typical but ineffective approach to school improvement. elementary and secondary each school).

r.
Building productive working relationship with
Determine the extent to which the school
engaged in practices likely to prompt schoo

improvement.
Framework included Learning leadership, and context.
Two schools and principals, one in

suburban school and one in a rural school.

Interviews; Participant observations.
10 schools.

Observations and interviews with head eachers, teachers, immigrant and native students, and their parents.
Leading in the suburban school included: teacher capacity; restructuring the school; establishing high performance expectations. included: acquiring knowledge about the community; building the capacity of the school developing a culture that supports a learning

the development of collaborative and inclusive school cultures, policies, and practices.

Nonetheless, collaborative and inclusive cultures, policies, and practices should be re-conceptualized and re-defined through the lens of social justice" Interviews with headteachers, member of the senior management team, middle 
Table A2. Cont.

Authors

Purposes

Guiding Concepts/Theories

Methods

Case studies of self-identified social justice principals' responses to
Rivera-McCabe, 2017 Describe how social justice leaders respond to [111] teacher prejudice.
Social justice leadership hypothetical cases of teacher prejudice

\section{General Results}

Primary source of guidance for these principals were their senses of moral obligation and their predispositions toward the goals of equity and fairness.

Hire staff committed to equity

Shape the school's curriculum and instruction in alignment with social justice goals; encourage staff to hold high expectations for their students; strong belief about students being able to do well; model the school's values; orient staff toward fighting

$$
\text { injustices; }
$$

created a climate of care.

Community oriented strategies for improving student success.

Results point to the importance of principals
Three elements of political acumen Understanding the political

environment; applying one's

Describe how principals use their political cumen to promote social justice in their schools. knowledge to the strategies being

$$
\text { own's actions }
$$

\section{4 principles}

Describe what social justice leaders do and what factors hinder the work of social justice leaders?

Determine how these people become social justice leaders.

(attributed to Priest et al., 2013):

. Economic justice

2. Cultural justice

3. Associational justic

4. Developmental justice.

Social justice leadership.

Describe school leadership practices in used; strategically monitoring one's
Interviews with 28

inclusive/equity-minded school

$$
\text { principals. }
$$

Cross-case analysis

3 schools in 3 Spanish-speaking countries.

Supervisor-nominated schools.

Semi-structured interviews with principals. ngaging in political activity in their organization

they need to combine their intellectual and strategic abilities with personal and social qualities like courage, boldness and care if they are to move their social justice agendas along.

Principals promoted social justice by: organizing students to help other students; developing

programs in sports and the arts with the intent to ncrease social cohesion; undertaking programs in emotional education; encouraging collaboration inside and outside of the schools.

Practices used by principals to overcome the

internal and external deficiencies in which they
Torres-Arcadia,

Rodríguez-Uribe \& Mora,

2018 [124] challenging (Mexican) contexts.
3 Mexican inner-city elementary schools Interviews with principals, teachers, students and parents. operate included: promoting order and discipline clarifying roles and rules, adapting to the context managing external support; developing students self-esteem and sense of belonging. 
Table A2. Cont.

Authors

Purposes

Describe how "school principals with social

ustice commitment understand and perceive

social justice in their leadership practices."

$$
\text { (p. 667) }
$$

Guiding Concepts/Theories

Wang, 2017 [126]

Determine subversive tactics that principals use in pursuit of justice and equity in schools and identify challenges and risks associated with

Power tactics their subversive leadership practices.

To investigate how principals promote social justice to redress marginalization, inequity and

divisive actions that are prevalent in schools.
Social justice leadership.

Methods

Interviews with 22 Ontario principal about work context, the meaning of social justice and examples of social justice leadership practices.

Semi-structured interviews 22 elementary and secondary principals in

the Greater Toronto Area.

Semi-structured interviews with
Semi-structured interviews with 22 elementary and secondary principals in the Greater Toronto Area.

\section{General Results}

Results "draw attention to the central importance of awareness of the social iniustices in schools-in che debate on what can bectice a den wat can be considered as leadership for social justice." (p. 667).

Participants had diverse views on social justice. Recognized that equity is a principle that is both thical and value laden. Principals from large and high-poverty schools were more likely to be

concerned with equity of resources and access. The majority of participants endorsed the value of representation and inclusion as elements of social

$$
\text { justice and equity. }
$$

To exercise "the ethics of subversion and critique, participants are more likely to use soft, rational, and bi/multilateral rather than hard, non-rational, 18 elementary and secondary principals in Metro Vancouver. their concern about causing relational harm and shows their strategic avoidance of direct confrontation."

Social justice leaders focus on people. Their people-centered leadership practices include: being positioning ase, putting students at the center, positioning as a social justice leader, developing through social justice, and fostering portive rough social justice, and fostering positive 


\section{References}

1. Lezotte, L.W. School Effectiveness: Reflections and Future Directions; The American Educational Research Association: San Francisco, CA, USA, 1986.

2. Gerard, H. School Desegregation: A Long-Term Study; Springer Science \& Business Media: Berlin/Heidelberg, Germany, 2013.

3. Baglieri, S. Disability Studies and the Inclusive Classroom: Critical Practices for Creating Least Restrictive Attitudes; Routledge: New York, NY, USA, 2012.

4. Wiliam, D. Standardized testing and school accountability. Educ. Psychol. 2010, 45, 107-122.

5. Huang, F. Prior problem behaviors do not account for the racial suspension gap. Educ. Res. 2020, 49, 493-502. [CrossRef]

6. Riddle, T.; Sinclair, S. Racial disparities in school-based disciplinary actions are associated with county-level rates of racial bias. Proc. Natl. Acad. Sci. USA 2019, 116, 8255-8260. [CrossRef] [PubMed]

7. Heckmann, F. Education and the Integration of Migrants: Challenges for European Education Systems Arising from Immigration and Strategies for the Successful Integration of Migrant Children in European Schools and Societies; NESSE Analytical Report 1 for Directorate General Education and Culture; EFMS: Bamberg, Germany, 2008.

8. Anyon, J. Radical Possibilities: Public Policy, Urban Education, and a New Social Movement, 2nd ed.; Routledge: New York, NY, USA, 2014.

9. Kerrissey, M.; Edmondson, A. What Good Leadership Looks like during This Pandemic. Harvard Business Review. 2020. Available online: https:/ /hbr.org/2020/04/what-good-leadership-looks-like-during-this-pandemic (accessed on 15 February 2021).

10. Learning Reimagined: Radical Thinking for Equitable Futures; Imaginable Futures and IDEO: Cambridge, MA, USA, 2020.

11. Leithwood, K.; Harris, A.; Hopkins, D. Seven strong claims about school leadership revisited. Sch. Leadersh. Manag. 2020, 40, 5-22. [CrossRef]

12. Leithwood, K.; Louis, K.S. Linking Leadership to Learning; Jossey-Bass: San Francisco, CA, USA, 2012.

13. Leithwood, K. The Ontario Leadership Framework with a Discussion of Its Research Foundations; Institute for Educational Leadership and the Ontario Ministry of Education: Toronto, CA, USA, 2012.

14. Leithwood, K. Integrated educational leadership. In Encyclopedia of Education, 4th ed.; Tierney, R., Rizvi, F., Ericikan, K., Smith, G., Eds.; Elsevier: Amsterdam, The Netherlands. (in press)

15. Leithwood, K.; Harris, A.; Hopkins, D. Seven strong claims about successful school leadership. Sch. Leadersh. Manag. 2008, 28, 27-42. [CrossRef]

16. Leithwood, K.; Patten, S.; Jantzi, D. Testing a conception of how leadership influences student learning. Educ. Adm. Q. 2010, 46, 671-706. [CrossRef]

17. Leithwood, K.; Riehl, C. What we already know about successful school leadership. In A New Agenda: Directions for Research on Educational Leadership; Firestone, W.A., Riehl, C., Eds.; Teachers College Press: New York, NY, USA, 2005 ; pp. 22-47.

18. Leithwood, K.; Sun, J.; Schumacker, R. How school leadership influences student learning: A test of "The four paths model". Educ. Adm. Q. 2020, 56, 570-599. [CrossRef]

19. Sun, J.; Leithwood, K. Transformational school leadership effects on student achievement. Leadersh. Policy Sch. 2012, 11, 418-451. [CrossRef]

20. Sun, J.; Leithwood, K. Direction-setting school leadership practices: A meta-analytic review of evidence about their influence. Sch. Eff. Sch. Improv. 2015, 26, 499-523. [CrossRef]

21. Leithwood, K.; Patrician, P. Changing the educational culture of the home to increase student success at school. Societies 2015, 5, 664-685. [CrossRef]

22. Leithwood, K.; Sun, J.; Pollock, K. (Eds.) How School Leaders Contribute to Student Success: The Four Paths Model; Springer: Amsterdam, NL, USA, 2017.

23. Marks, S.; Printy, H. Principal leadership and school performance: An integration of transformational and instructional leadership. Educ. Adm. Q. 2003, 39, 370-397. [CrossRef]

24. Galloway, M.; Ishimura, A. Radical recentering: Equity in educational leadership standards. Educ. Adm. Q. 2015, 51, 372-408. [CrossRef]

25. Ishimaru, A.; Galloway, M. Beyond individual effectiveness: Conceptualizing organizational leadership for equity. Leadersh. Policy Sch. 2014, 13, 93-146. [CrossRef]

26. Khalifa, M.A.; Gooden, M.A.; Davis, J.E. Culturally responsive school leadership: A synthesis of the literature. Rev. Educ. Res. 2016, 86, 1272-1311. [CrossRef]

27. Riehl, C.J. The principal's role in creating inclusive schools for diverse students: A review of normative, empirical, and critical literature on the practice of educational administration. Rev. Educ. Res. 2000, 70, 55-81. [CrossRef]

28. Peterson, R.S.; Smith, D.B.; Martorana, P.V.; Owens, P.D. The impact of chief executive officer personality on top management team dynamics: One mechanism by which leadership affects organizational performance. J. Appl. Psychol. 2003, 88, 795-808. [CrossRef]

29. Schutte, N.S.; Malouff, J.M.; Thorsteinsson, E.B. Increasing emotional intelligence through training: Current status and future directions. Int. J. Emot. Educ. 2013, 5, 56-72. 
30. Cranston, N.; Ehrich, L.C.; Kimber, M. Managing ethical dilemmas. In Handbook of Ethical Educational Leadership; Branson, C.M., Gross, S.J., Eds.; Routledge: New York, NY, USA, 2014; pp. 229-245.

31. Hallinger, P. Leadership for learning: Lessons from 40 years of empirical research. J. Educ. Adm. 2011, 49, 125-142. [CrossRef]

32. Day, C.; Gu, Q.; Sammons, P. The impact of leadership on student outcomes: How successful school leaders use transformational and instructional strategies to make a difference. Educ. Adm. Q. 2016, 52, 221-258. [CrossRef]

33. Furman, G. Social justice leadership as praxis: Developing capacities through preparation programs. Educ. Adm. Q. 2012, 48, 191-229. [CrossRef]

34. Oplatka, I. The Legacy of Educational Administration: A Historical Analysis of an Academic Field; Peter Lang: Frankfurt am Main, Germany, 2010.

35. Silva, J.; White, G.; Yoshida, R. The direct effects of principal-student discussions on eighth grade students' gains in reading achievement: An experimental study. Educ. Adm. Q. 2011, 47, 772-793. [CrossRef]

36. Demie, F. Raising achievement of black Caribbean pupils: Good practice for developing leadership capacity and workforce diversity in schools. Sch. Leadersh. Manag. 2019, 39, 5-25. [CrossRef]

37. Pashiardis, P.; Savvides, V. The interplay between instructional and entrepreneurial leadership styles in Cyprus rural primary schools. Leadersh. Policy Sch. 2011, 10, 412-427. [CrossRef]

38. Notman, R.; Henry, A. Building and sustaining successful school leadership in New Zealand. Leadersh. Policy Sch. 2011, 10, 375-394. [CrossRef]

39. Irvine, A.; Lupart, J.; Loreman, T.; McGhie-Richmond, D. Educational leadership to create authentic inclusive schools: The experiences of principals in a Canadian rural school district. Except. Educ. Int. 2010, 20, 70-88. [CrossRef]

40. Nabhani, M.; Busher, H.; Bahous, R. Cultures of engagement in challenging circumstances: Four Lebanese primary schools in urban Beirut. Sch. Leadersh. Manag. 2012, 32, 37-55. [CrossRef]

41. Szeto, E.; Cheng, A.Y.N. How do principals practise leadership for social justice in diverse school settings? A Hong Kong case study. J. Educ. Adm. 2017, 56, 50-68. [CrossRef]

42. Theoharis, G.; O’Toole, J. Leading inclusive ELL: Social justice leadership for English language learners. Educ. Adm. Q. 2011, 47, 646-688. [CrossRef]

43. Gurr, D.; Drysdale, L.; Longmuir, F.; McCrohan, K. The leadership, culture and context nexus: Lessons from the leadership of improving schools. Int. Stud. Educ. Adm. 2018, 46, 22-44.

44. Green, T. Leading for urban school reform and community development. Educ. Adm. Q. 2015, 51, 679-711. [CrossRef]

45. Klar, H.W.; Brewer, C.A. Successful leadership in a rural, high-poverty school: The case of County Line Middle School. J. Educ. Adm. 2014, 52, 422-445.

46. Ishimura, A. From heroes to organizers: Principals and education organizing in urban school reform. Educ. Adm. Q. 2013, 49, 3-51. [CrossRef]

47. Okilwa, N.; Barnett, B. Four successive school leaders' response to a high needs urban elementary school context. Int. Stud. Educ. Adm. 2017, 46, 45-86.

48. Bills, A.; Cook, J.; Giles, D. Understanding emancipatory forms of educational leadership through schooling justice work: An action research study into second chance schooling development. Sch. Leadersh. Manag. 2015, 35, 502-523. [CrossRef]

49. McCormick, T.; Tino, N. Low vs. high expectations: A review of teacher expectations effects on minority students. J. Equity Leadersh. 1986, 6, 224-234.

50. Gurr, D. A model of successful school leadership from the international successful school principalship project. Societies 2015, 5, 136-150.

51. Pashiardis, P.; Savvides, V.; Lytra, E.; Angelidou, K. Successful school leadership in rural contexts: The case of Cyprus. Educ. Manag. Adm. Leadersh. 2010, 39, 536-553. [CrossRef]

52. Klar, H.; Brewer, C. Successful leadership in high-needs schools: An examination of core leadership practices enacted in challenging contexts. Educ. Adm. Q. 2013, 49, 768-808. [CrossRef]

53. Avolio, B.J.; Gardner, W.L. Authentic leadership development: Getting to the root of positive forms of leadership. Leadersh. Q. 2005, 16, 315-338. [CrossRef]

54. Brown, M.E.; Treviño, L.K. Ethical leadership: A review and future directions. Leadersh. Q. 2006, 17, 595-616. [CrossRef]

55. Okilwa, N.; Barnett, B. Sustaining school improvement in a high needs school: Longitudinal analysis of Robbins Elementary School (USA) from 1993 to 2015. J. Educ. Leadersh. 2017, 55, 297-315. [CrossRef]

56. Wilson, C. Enacting critical care and transformative leadership in schools highly impacted by poverty: An African American principal's counter-narrative. Int. J. Leadersh. Educ. 2016, 19, 557-577. [CrossRef]

57. Preston, J.; Claypool, T.; Rowluck, W.; Green, B. Perceptions and practices of principals: Supporting positive educational experiences for Aboriginal learners. Int. J. Leadersh. Educ. 2017, 20, 328-344. [CrossRef]

58. Jacobson, S.; Notman, R. Leadership in early childhood education: Implications for parental involvement and student success from New Zealand. Int. Stud. Educ. Adm. 2018, 46, 86-101.

59. Khalifa, M. A re-new-ed paradigm in successful urban school leadership: Principal as community leader. Educ. Adm. Q. 2012, 48, 424-467. [CrossRef]

60. Marzano, R. What Works in Schools: Translating Research into Action; Association for Supervision and Curriculum Development (ASCD): Alexandria, VA, USA, 2003. 
61. Smylie, M.A.; Murphy, J.; Seashore Louis, K. Caring school leadership: A multidisciplinary, cross-occupational model. Am. J. Educ. 2016, 123, 1-35. [CrossRef]

62. Fass, D.; Smith, A.; Darmody, M. The role of principals in creating inclusive school environments: Insights from community national schools in Ireland. Sch. Leadersh. Manag. 2018, 38, 457-473. [CrossRef]

63. Qin, L.; Bowen, D. The distribution of teacher qualification: A cross-national study. Int. J. Educ. Dev. 2019, 70, 102084. [CrossRef]

64. Clotfelter, C.T.; Ladd, H.F.; Vigdor, J.L.; Wheeler, J. High poverty schools and the distribution of teachers and principals. N. C. Law Rev. 2007, 85, 1345-1379.

65. Buckley, J.; Schneider, M.; Shang, Y. Fix it and they might stay: School facility quality and teacher retention in Washington, DC. Teach. Coll. Rec. 2005, 107, 1107-1123. [CrossRef]

66. Ladd, H.F. Teachers' perceptions of their working conditions: How predictive of planned and actual teacher movement? Educ. Eval. Policy Anal. 2005, 33, 235-261. [CrossRef]

67. Hanushek, E.A.; Rivkin, S.G.; Schiman, J.C. Dynamic effects of teacher turnover on the quality of instruction. Econ. Educ. Rev. 2016, 55, 132-148. [CrossRef]

68. Ronfeldt, M.; Loeb, S.; Wyckoff, J. How teacher turnover harms student achievement. Am. Educ. Res. J. 2013, 50, 4-36. [CrossRef]

69. Viano, S.; Pham, L.; Henry, G.; Zimmer, R. What teachers want: School factors predicting teachers' decisions to work in low-performing schools. Am. Educ. Res. J. 2021, 58, 201-233. [CrossRef]

70. Klar, H.W.; Brewer, C.; Whitehouse, M.L. AVIDizing a high-poverty middle school: The case of Magnolia Grove. Int. J. Res. Pract. Stud. Engagem. 2013, 1, 9-23.

71. Shaked, H.; Schechter, C. School principals as mediating agents in education reforms. Sch. Leadersh. Manag. 2017, 37, 19-37. [CrossRef]

72. Leithwood, K.; Jantzi, D.; Dart, B. Transformational leadership: How principals can help reform school cultures. Sch. Eff. Sch. Improv. 1990, 1, 249-280. [CrossRef]

73. Jorgensen, R.Z.; Niesche, R. Equity, mathematics and classroom practice: Developing rich mathematical experiences for disadvantaged students. Aust. Prim. Math. Classr. 2008, 13, 21-27.

74. Lingard, B.; Mills, M. Pedagogies making a difference: Issues of social justice and inclusion. Int. J. Incl. Educ. 2007, 11, 233-244 [CrossRef]

75. Ladson-Billings, G. Toward a theory of culturally relevant pedagogy. Am. Educ. Res. J. 1995, 32, $465-491$.

76. Bereiter, C.; Scardamalia, M. Education for the knowledge age: Design-centered models of teaching and instruction. In Handbook of Educational Psychology; Alexander, P.A., Winne, P.H., Eds.; Lawrence Erlbaum Associates: Mahwah, NJ, USA, 2006; pp. 695-713.

77. Darling-Hammond, L.; Flook, L.; Cook-Harvey, C.; Barron, B.; Osher, D. Implications for educational practice of the science of learning and development. Appl. Dev. Sci. 2018, 24, 97-140. [CrossRef]

78. Resendes, M.; Dobbie, K. Knowledge building gallery: Teaching for deep understanding and community knowledge creation. In Leading Student Achievement: Networks for Learning Project; Maika, D., Hine, E., Ma, L., Heaver, E., White, L., Eds.; 2017 ; pp. 15-165. Available online: https:/ / thelearningexchange.ca/wp-content/uploads/2017/04/Knowledge-Building-Booklet-Accessible-1. pdf (accessed on 15 January 2021).

79. Angelides, P.; Antoniou, E.; Charalampous, C. Making sense of inclusion for leadership and schooling: A case study from Cyprus. Int. J. Leadersh. Educ. 2010, 13, 319-334. [CrossRef]

80. Mitra, D. Student voice in secondary schools: The possibility for deeper change. J. Educ. Admin. 2018, 56, 473-487. [CrossRef]

81. Drysdale, L.; Goode, H.; Gurr, D. An Australian model of successful school leadership. J. Educ. Adm. 2009, 47, 697. [CrossRef]

82. Robinson, V.; Lloyd, C.; Rowe, K. The impact of leadership on student outcomes: An analysis of the differential effects of leadership types. Educ. Adm. Q. 2008, 44, 635-674. [CrossRef]

83. Volante, L.; Ben Jaafar, S. Profiles of education assessment systems worldwide: Educational assessment in Canada. Assess. Educ. 2008, 15, 201-210. [CrossRef]

84. May, H.; Huff, J.; Goldring, E. A longitudinal study of principals' activities and student performance. Sch. Eff. Sch. Improv. 2012, 23, 417-439. [CrossRef]

85. Adams, C.M.; Olsen, J.J.; Ware, J.K. The School Principal and Student Learning Capacity. Educ. Adm. Q. 2017, 53, 556-584. [CrossRef]

86. Sebastian, J.; Allensworth, E. The influence of principal leadership on classroom instruction and student learning: A study of mediated pathways to learning. Educ. Adm. Q. 2012, 48, 626-663. [CrossRef]

87. Sebastian, J.; Allensworth, E.; Huang, H. The role of teacher leadership in how principals influence classroom instruction and student learning. Am. J. Educ. 2016, 123, 69-108. [CrossRef]

88. Sebastian, J.; Allensworth, E.; Stevens, D. The influence of school leadership on classroom participation: Examining configurations of organizational supports. Teach. Coll. Rec. 2014, 116, 1-36.

89. Sebastian, J.; Allensworth, E.; Wiedermann, W.; Hochbein, C.; Cunningham, M. Principal leadership and school performance: An examination of instructional leadership and organizational management. Leadersh. Policy Sch. 2019, 18, 591-613. [CrossRef]

90. Sebastian, J.; Huang, H.; Allensworth, E. Examining integrated leadership systems in high schools: Connecting principal and teacher leadership to organizational processes and student outcomes. Sch. Eff. Sch. Improv. 2017, 28, 463-488. [CrossRef]

91. Yoon, S.Y. Principals' data-driven practice and its influences on teacher buy-in and student achievement in comprehensive school reform models. Leadersh. Policy Sch. 2016, 15, 500-523. [CrossRef] 
92. Grissom, J.A.; Loeb, S. Triangulating principal effectiveness: How perspectives of parents, teachers, and assistant principals identify the central importance of managerial skills. Am. Educ. Res. J. 2011, 48, 1091-1123. [CrossRef]

93. Leithwood, K. Four reasons why leadership vs. management is a dangerously flawed distinction. Princ. Connect. 2015, 19, 4-7.

94. Scanlan, M.; Lopez, F. Vamos! How school leaders promote equity and excellence for bilingual students. Educ. Adm. Q. 2012, 48, 583-625. [CrossRef]

95. Capper, C. The 20th-year anniversary of Critical Race Theory in education: Implications for leading to eliminate racism. Educ. Adm. Q. 2015, 51, 791-833. [CrossRef]

96. Khalifa, M.; Khalil, D.; Marsh, T.; Halloran, C. Toward an Indigenous, decolonizing school leadership: A literature review. Educ. Adm. Q. 2019, 55, 571-614. [CrossRef]

97. Hallinger, P.; Leithwood, K. Culture and educational administration: A case of finding out what you don't know you don't know. J. Educ. Adm. 1996, 34, 98-116. [CrossRef]

98. Grissom, J.; Egalite, A.; Lindsay, C. How Principals Affect Students and Schools: A Systematic Synthesis of Two Decades of Research; The Wallace Foundation: 2021. Available online: http:/ /www.wallacefoundation.org/principalsynthesis (accessed on 15 February 2021).

99. Silva, J.; Slater, C.; Gorosave, G.; Cerdas, V.; Torres, N.; Antunez, S.; Briceno, F. Educational leadership for social justice in Costa Rica, Mexico and Spain. J. Educ. Leadersh. 2017, 55, 316-333. [CrossRef]

100. Muijs, D.; Ainscow, M.; Dyson, A.; Raffo, C.; Goldrick, S.; Kerr, K.; Lennie, C.; Miles, S. Leading under pressure: Leadership for social inclusion. Educ. Manag. Adm. Leadersh. 2010, 30, 143-157. [CrossRef]

101. Ezzani, M.; Brooks, M. Culturally relevant leadership: Advancing critical consciousness in American Muslim students. Educ. Adm. Q. 2019, 55, 781-811. [CrossRef]

102. Cruz, A.; Lopez, F. Equity and excellence among Arizona school leaders: Encouraging integration within a segregative policy context. Leadersh. Policy Sch. 2020, 19, 81-103. [CrossRef]

103. Cruz-Gonsalez, C.; Munoz, M.; Segovia, J. Marta's story: A female principal leading in challenge contexts. Sch. Leadersh. Manag. 2020, 40, 384-405. [CrossRef]

104. Hajisoteriou, C.; Karousiou, C.; Angelides, P. Successful components of school improvement in culturally diverse schools. Sch Eff. Sch. Improv. 2018, 29, 91-112. [CrossRef]

105. Fitzgerald, T. Spaces in-between; Indigenous women leaders speak back to dominant discourses and practices in educational leadership. Int. J. Leadersh. Educ. 2010, 13, 93-105. [CrossRef]

106. DeMatthews, D. Making sense of social justice leadership: A case study of a principal's experience to create a more inclusive school. Leadersh. Policy Sch. 2015, 14, 139-166. [CrossRef]

107. Ryan, J. Promoting social justice in schools: Principals' political strategies. J. Leadersh. Educ. 2010, 13, 357-376. [CrossRef]

108. Ryan, J. Strategic activism, educational leadership and social justice. Int. J. Leadersh. Educ. 2016, 19, 87-100.

109. Wang, F. Social justice leadership-Theory and practice: A case of Ontario. Educ. Adm. Q. 2018, 54, 470-498. [CrossRef]

110. Ishimura, A. Re-imagining turnaround: Families and communities leading educational justice. J. Educ. Adm. 2018, 56, 546-561. [CrossRef]

111. Rivera-McCabe, R. The moral imperative of social justice leadership: A critical component of effective practice. Urban Rev. 2017, 46, 747-763. [CrossRef]

112. Hogg, L.; Volman, M. A synthesis of funds of identity research: Purposes, tools, pedagogical approaches and outcomes. Rev. Educ. Res. 2020, 90, 862-895.

113. Volman, M. The effects of using students' funds of knowledge on educational outcomes in the social and personal domain. Learn. Cult. Soc. Interact. 2021, 28, 100472. [CrossRef]

114. Rios-Aguilar, C. Measuring funds of knowledge: Contributions to Latina/o students' academic and nonacademic outcomes. Teach. Coll. Rec. 2010, 112, 2209-2257.

115. Blazar, D.; Archer, C. Teaching to support students with diverse academic needs. Educ. Res. 2020, 49, $297-311$.

116. DeMatthews, D.; Mawhiney, H. Social justice leadership and inclusion: Exploring challenges in an urban district struggling to address inequities. Educ. Adm. Q. 2014, 50, 844-881. [CrossRef]

117. Garza, E.; Murakami-Ramalho, E.; Merchant, B. Leadership succession and successful leadership: The case of Laura Martinez. Leadersh. Policy Sch. 2011, 10, 428-443. [CrossRef]

118. Medina, V.; Martinez, G.; Murakami, E.T.; Rodriguez, M.; Hernandez, F. Principals' perceptions from within: Leadership in high-need schools in the USA. Manag. Educ. 2014, 28, 91-96. [CrossRef]

119. Moral, C.; Higueras, L.; Martin-Romero, A.; Martinez-Valdivia, E.; Morales-Ocana, A. Effective practices in leadership for social justice. Evolution of successful secondary school principalship in disadvantaged contexts. Int. J. Leadersh. Educ. 2020, 23, 107-130. [CrossRef]

120. Szeto, E.; Cheng, A.Y.; Sin, K.K. Challenges of difference and difficulty: How do principals enact different leadership for diverse student population in a changing Chinese school context? Int. J. Leadersh. Educ. 2019, 22, 519-535. [CrossRef]

121. Chang, E. Bridging an engagement gap: Towards equitable, community-based technology leadership practice. Int. J. Leadersh. Educ. 2019, 22, 536-554. [CrossRef]

122. Heystek, J.; Lumby, J. Identity and diversity: A case study of leaders in a South African primary school. Educ. Chang. 2011, 15, 331-343. [CrossRef] 
123. Murakami, E.; Kearney, S.; Scott, L.; Alfaro, P. Leadership for the improvement of a high poverty/high minority school. Int. Stud. Educ. Adm. 2017, 45, 2-21.

124. Torres-Arcadia, C.; Rodriguez-Uribe, C.; Mora, G. How principals lead high needs schools in Mexico. Int. Stud. Educ. Adm. 2018, $46,123-147$.

125. Wang, F. Conceptualizing social justice: Interviews with principals. J. Educ. Adm. 2015, 53, 667-681. [CrossRef]

126. Wang, F. The Ontario quandary: Principals' perceptions of accountability policy and social justice. J. Sch. Leadersh. 2017, 27, 392-420. [CrossRef]

127. Wang, F. Subversive leadership and power tactics. J. Educ. Leadersh. 2018, 56, 398-413. [CrossRef] 